\title{
Versiones y aversiones al paisaje andino (Siete últimos acercamientos desde la arquitectura)
}

\author{
José Luis Falconi' y Javiera Infante ${ }^{2}$
}

\section{Andes Pacífico o la intimidad de lo sublime}

\section{Introducción}

¡Qué sublimes se sienten (y se venden) los paisajes de los Andes de Colombia, Ecuador, Perú y Chile!

Efectivamente: las postales nacionales de cada uno de estos países nos presentan una diversidad enorme de paisajes -todos diferentes, pero cada uno de ellos casi siempre recubiertos con una sensación de una grandeza absoluta, de un sentimiento absorbente y de emociones penetrantes. Y es que ¿qué podría ser más sublime que las tierras calientes del Chocó, la grandeza del Pichincha, el austero desierto sin vida de las costas peruanas, o los macizos helados y alejados de Torres del Paine?

Estos paisajes, vistos siempre como si fueran postales lejanas, han ido generando una suerte de imaginario colectivo de admiración, nostalgia e imposibilidad de apropiación: son territorios sublimes, edenes perdidos inalcanzables para la especie humana, sitios mitológicos e incomprensibles. Son geografías indomables. $Y$ es que lo que sucede entre los Andes y el Pacífico es geográficamente especial por ser diverso y furioso. La pendiente existente por la corta distancia entre la cordillera y el mar genera esa cantidad interminable de pisos vegetacionales, tantas veces revisados en los preciosos dibujos de Humboldt, unos detrás de otros, unidos por esos hilos inagotables de torrentosas cuencas que los riegan: una red de aguas pacíficas que permiten estas ecologías de los Andes (von Humboldt y Bonpland, 1807).

Recordemos que este paisaje es una larga y angosta franja que cruza de norte a sur todo el subcontinente suramericano desde la latitud $11^{\circ} \mathrm{N}$ en la Sierra Nevada de Santa Marta a la latitud $55^{\circ} \mathrm{S}$ en el Cabo de Hornos. Esta

$\overline{1}$ Peruano. Ph.D. in Romance Languages and Literatures por la Harvard University, Cambridge, MA. Docente del Department of History of Art and Architecture, Harvard University. Correo electrónico: falconi@artlifelaboratory.com

2 Chilena. Magister en Arquitectura del Paisaje por la Pontificia Universidad Católica de Chile. Coordinadora Académica de la Maestría en Arquitectura y Procesos Proyectuales, Pontificia Universidad Católica del Perú. Correo electrónico: javierainfante@gmail.com 
línea intermedia y estrecha entre el océano Pacífico y la cordillera de los Andes provoca que los ecosistemas que allí se generan sean intensos y concentrados en pequeños espacios. En esta franja no existen grandes extensiones que se pierden en el horizonte: desde la selva en Colombia hasta la Patagonia en Chile, el paisaje se ve siempre encerrado entre montañas.

Sin embargo, viéndolo desde un punto de vista histórico, es evidente que las ciudades más importantes de la región fueron dadas y siguen desarrollándose sobre estos paisajes andinos, exuberantes e inhóspitos, y que han forjado, en cierta manera, los caracteres nacionales. Siguiendo a Jackson, uno también podría decir:

Y lo que confirmó mi amor por el paisaje así establecido fue la tendencia ... a analizarlo no simplemente como un producto accidental de fuerzas económicas o medioambientales, sino como expresión profunda de características étnicas o raciales. El paisaje ancestral creó una casta especial de hombres y mujeres con características psicológicas y físicas en común. Esto sucedió tras siglos de apego físico al territorio; fue solo a través de un enraizamiento con la tierra, de tener un pasado de campesino o terrateniente, de haber superado las inefables influencias de un tipo de clima y de una cierta topografía, que emergió el verdadero alemán, inglés o francés (Jackson, 2012, p. 26).

¿Cómo es, entonces, el verdadero paisaje colombiano, ecuatoriano, peruano y chileno? ¿Cómo ha sido esa relación de apego entre el hombre y la mujer sudamericana de la cuenca del Pacífico y la naturaleza, entre el ser humano y su entorno desbordado que parece haberlo conquistado íntimamente? ¿Hay, acaso, una (muy sublime) conquista andina?

Si bien es complejo -si no imposible- establecer categorías absolutas con respecto a estas preguntas, lo que sí parece una constante valiosísima es que, en definitiva, la ciudad andina (Medellín, Bogotá, Quito, Santiago, entre otras) es toda ella un paisaje visible: sistemas urbanos rodeados de montañas cafés, amarillas, verdes o blancas y surcadas por quebradas con mayores o menores caudales de agua que los cruzan a diestra y siniestra. Y, en este sentido, la cantidad de visiones en torno al tema que se superponen en esta región desde la historia, lo político, lo económico y lo social, lo complejiza de manera tal que termina por explotar en un palimpsesto de visiones: desde la cosmovisión milenaria del andino; el entendimiento del paisaje americano por las expediciones botánicas de Mutis, Humboldt, Darwin y tantos otros; o el paisaje republicano luego de la independencia de España; hasta la visión neoliberal del territorio americano como una mina inagotable de explotación de recursos ${ }^{3}$.

Contrastar estas visiones históricas con el contexto actual -en el que la tecnología y las herramientas digitales, el big data, los desastres naturales, el

3 Se refiere a las expediciones de naturalistas europeos que se realizaron en América principalmente entre los siglos XVIII y XIX. 
calentamiento global, la desigualdad social, las preocupaciones por la ciudad, el transporte y la contaminación del aire son temas esenciales en las agendas urbanas y para el desarrollo de la región- pareciera clave para reflexionar en torno a cuál es nuestro rol, cuál es nuestra posición como hombres y mujeres andinos frente a este paisaje. Sin duda, la noción de riesgo en esta relación ha sido fundante en la empresa humana de conquistar el entorno andino, de manejarlo, de seguir en él a través del tiempo: de hacer el esfuerzo racional, físico e incluso espiritual para construir obras que contuvieran las crecidas de las torrentosas aguas andinas, de construir puentes que posibilitaran cruzar sus ríos y conectar sus montañas.

Fue en torno a estas ideas que José Luis Falconi y la que escribe comenzamos a organizar una serie de conversaciones con algunos de los más importantes arquitectos que han confrontado en su práctica este problema en la región para poder contrastar sus experiencias y recoger sus intuiciones con respecto a estos paisajes. Si bien éramos conscientes de que son muchos los que están pensando, escribiendo y enseñando acerca de estas temáticas, quisimos concentrarnos en la práctica proyectual por la condición transformadora que tiene sobre el espacio físico mismo y por todo el proceso que el proyecto conlleva, el cual introduce temas sociales, administrativos, políticos, económicos, culturales, históricos, entre otros.

En definitiva, lo que queríamos era lograr una "pausa" para conversar y reflexionar acerca de cómo entendemos este paisaje latinoamericano y, en específico, la ciudad andina, esas colonias que fueron justamente fundadas en el eje de los Andes. Queríamos investigar de dónde viene y hacia dónde va esa ciudad que crece a la velocidad del rayo, y que, por distintos procesos políticos, económicos y sociales (entre muchos otros), se ha desarrollado sobre un territorio que, más allá de la nostalgia, parecemos no entender, reconocer ni valorar como sistema global.

Para ello, buscamos en Colombia a Alejandro Echeverri, para conversar acerca de la experiencia y el rol que ha tenido su trabajo para la transformación de Medellín, primero desde la alcaldía de Sergio Fajardo (2004-2007) hasta la actualidad, en Urbam de la Universidad Eafit, a partir del entendimiento del urbanismo social como punto de partida para la transformación del paisaje de la ciudad para las personas; luego, nos encontramos con Pedro Aparicio y Felipe Guerra, quienes dirigen Altiplano, una oficina de arquitectura en Bogotá, donde reflexionamos en torno a la disociación física y hasta psicológica que existe en el imaginario entre la ciudad y "el monte", y cómo esto afecta en el entendimiento del paisaje en los nuevos concursos de proyectos de paisaje en 
la actualidad4 4 . En Ecuador, conversamos con Ernesto Bilbao, ganador del concurso Parque Bicentenario, que planteó un nuevo uso para el espacio del antiguo aeropuerto Mariscal Sucre de Quito, quien por medio de su práctica busca reconciliar los ecosistemas originales de los sitios con proyectos contemporáneos.

Siguiendo al Perú, entrevistamos a Jean Pierre Crousse, socio de Barclay \& Crousse, y conversamos acerca del especial interés que tiene su estudio por entender los proyectos como parte del paisaje peruano y no solamente como un objeto situado sobre él. También, conversamos con Michelle Llona y Rafael Zamora, socios del estudio LLONAZAMORA, acerca de la ausencia de la noción de "lo colectivo", que se traduce en la falta de inversión en lo público para proyectos de ciudad y paisaje para los ciudadanos en el país.

En Chile, hablamos con Sandra Iturriaga, directora de Mapocho 42K, proyecto que pretende transformar la costanera sur de este río santiaguino en un espacio público que conecte social y geográficamente a la ciudad. Por último, conversamos con el conocido arquitecto Teodoro Fernández acerca de los posibles inicios del "paisaje chileno" desde la noción agrícola y cómo la zona central del país se fue desarrollando en torno a esta idea por medio de proyectos de ciudad que siguen hasta hoy.

De la lectura de las conversaciones pareciera que se desprende una conclusión general: los nuevos proyectistas tienen muy en claro que más allá de la atmósfera nostálgica generalizada que existe en la región referente al "Edén perdido", en Latinoamérica ya no existe naturaleza intocada. El paisaje latinoamericano es artificial, en casi su totalidad. Hemos creado nuestras ciudades, nuestras regiones y nuestros países desde la ciudad y desde la infraestructura para la explotación del territorio. La relación romántica ya no es con la naturaleza virgen, sino con el paisaje diario que tenemos y lo que vamos construyendo día a día.

Por ello, nuestras ciudades andinas actuales ya son un pendiente continuo, situadas en una pendiente geográfica real y aguda. En la mayoría de los casos, la informalidad ha ido carcomiendo con cemento y ladrillo aquello que siempre vimos como espacio natural. Y, a pesar de que hoy pareciera seguir vigente en el imaginario que la relación ciudad/naturaleza se da de manera separada, la verdad es que no ocurre así: todo está conectado en una relación sistémica-un espacio físico donde lo medioambiental, la ocupación humana, la economía, la conectividad, las aguas, las dinámicas urbanas o rurales, la cultura y la sociedad pasan, con mayor o menor densidad, en simultáneo. Y

$4 \quad$ Sergio Fajardo fue alcalde de la ciudad de Medellín de 2004 a 2007, período en el cual Alejandro Echeverri estuvo a cargo de la Empresa de Desarrollo Urbano. 
esto se demuestra, una y otra vez, en las respuestas de los arquitectos, que plantean la vida diaria de la urbe andina como el gran paisaje que modificar.

Muchos de ellos señalan lo difícil que es pensar en el paisaje en la actualidad, en cuanto la economía imperante en nuestra región le ha puesto valor a cada pedazo de suelo, por lo que pensar en "lo público" cuando se está pensando en proyectos de paisaje, es asumir grandes inversiones económicas y largos períodos de proyectos que sobrepasan las administraciones políticas o son problemáticas de invasiones ilegales que tienen un trasfondo difícil de formalizar. Un futuro provechoso pareciera dejar de mirar el paisaje únicamente como "un suelo base" y empezar a entenderlo en profundidad, como si nos pidiera a gritos que lo conozcamos mejor, que lo trabajemos mejor: como si nos pidiera incesantemente más intimidad. Eso, pareciera, es el nuevo sublime que se abre.

Como siempre, en esta primera aproximación se nos quedaron muchas preguntas en el tintero, entre ellas: ¿cómo incorporamos el conocimiento y el ingenio que se desarrolla espontáneamente en nuestros territorios con una planificación más estratégica? ¿Cómo incluimos tecnologías para hacer ciudades más resilientes aprovechando el conocimiento colectivo? ¿Cómo articulamos nuestros hechos geográficos -tan presentes en esta región del mundo- para volverlas una infraestructura para todos?

Por lo pronto, las conversaciones aquí reunidas nos plantean que necesitamos urgentemente una visión mucho más amplia y holística para entender esta red de muchas capas que conforman nuestro espacio físico. Los proyectos de paisaje son tan grandes, abarcan tantas dimensiones del espacio y responden a sistemas tan complejos, que pareciera que dentro de la arquitectura ya no es posible resolverlos aisladamente. En otras palabras, se necesitan equipos interdisciplinarios para entender el territorio dinámicamente, para llegar a diseñar más que proyectos de formas cerradas y definidas -como suele hacerlo la arquitectura tradicional-, a alinear procesos que construyan nuevos relatos de paisaje, de ciudad y de personas.

Por ello, esperamos que estas conversaciones hagan reflexionar acerca de cuánto más hay que avanzar en el campo de la paisajística en nuestra región -un esfuerzo que comienza, como todos los entrevistados han señalado, en salirse de la noción del paisaje como postal, como ese espectáculo instagrameable. Si entendemos que el paisaje es eso que nos moldea como somos, como dice una de las entrevistadas, nos daremos cuenta de que este es también "el que nos da el sentido de pertenencia de ser ciudadanos". Una lección que, en términos cívicos, es ya un gran avance para nuestras sociedades.

Javiera Infante

Lima, marzo de 2018 


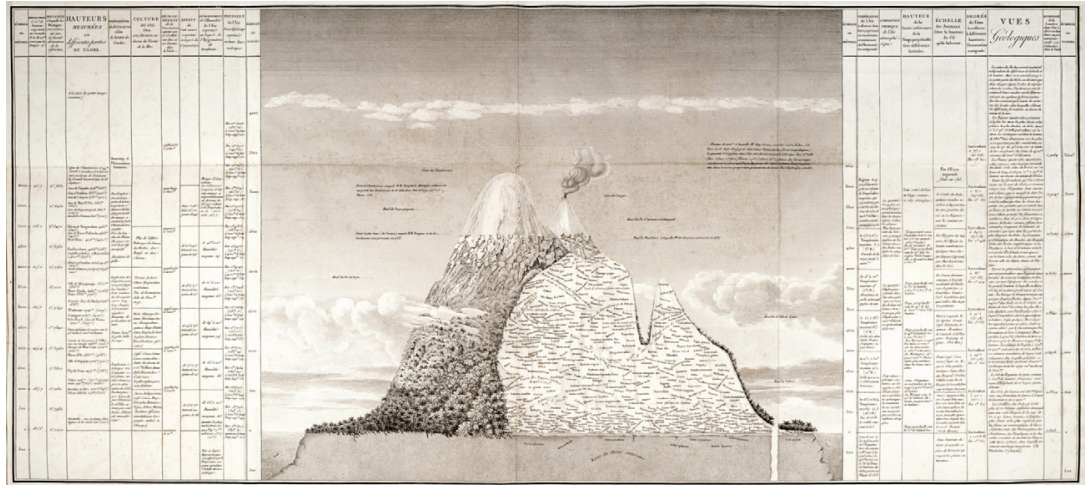

GÉOGRAPHIE DES PLANTES ÉQUINOXILALS.

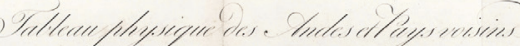

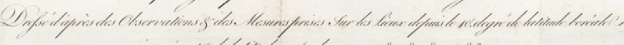

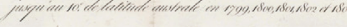

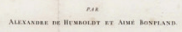

Figura 1. El Géographie des Plantes Équinoxiales, de Alexander von Humboldt y Aimé Bonpland, fue el primer dibujo científico que describe los distintos sistemas ecológicos por altura en Los Andes, como unidad interrelacionada (Von Humboldt, Alexander; Bonpland, Aimé (1807). Ideen zu einer Geographie der Pflanzen usf. Tübingen: Bey F. G. Cotta).

\section{ENTREVISTA A ALEJANDRO ECHEVERRI}

\section{Medellín, Colombia}

Falconi/Infante: Alejandro, ¿qué significa para ti el tema del paisaje dentro de tu propia práctica arquitectónica? ¿Cómo has venido desarrollando este tema para el caso de Medellín, en estos últimos años?

Echeverri: Yo creo que en el caso particular de Medellín (y que es quizás aplicable para Latinoamérica), uno no puede separar la ciudad de su entorno natural.

Yo empecé a trabajar en las laderas, los barrios de la zona norte de la ciudad y fue realmente esto lo que me llevó a comenzar a entender los procesos urbanos de forma más simbiótica, la relación entre el trazado de calles, el relieve geográfico con sus habitantes. Porque, como tú sabes, Medellín es un lugar arrugado, con relieve, es una región de montañas y nosotros no podemos disociarnos de ellas: cómo esta geografía condiciona los hábitos de vida y, por tanto, condiciona la forma como pensamos nuestras propuestas. 
Falconi/Infante: ¿Cómo así?

Echeverri: Al entender que todos los procesos urbanos de los habitantes de la ciudad, y especialmente de las laderas, viven en esta condición simbiótica entre el agua y las pendientes, me empecé a obsesionar por la idea de que Medellín es un valle cerrado, una cuenca de más de 250 quebradas (cañadas), que descienden por las laderas desde la parte alta, cortando y cruzando toda la urbe hasta llegar al río y, así, que gran parte de la historia de los barrios tiene que ver con las líneas del agua. Tenemos los barrios de mayor pendiente que han nacido bajo ocupaciones informales alrededor de las quebradas, pero también las zonas industriales que comenzaron a existir por la producción de energía, a partir de pequeñas plantas eléctricas localizadas en las quebradas. Es decir, hay una historia que relaciona el relieve geográfico y los sistemas naturales con una gran cantidad de hechos, de los que no se pueden separar, como la forma urbana y la vida de la ciudad.

Mi iniciación al tema de la ciudad resultó de dibujar a Medellín en relación con las huellas del agua (el relieve) y su fricción y crisis, con el trazado de calles. Fue un camino diferente, pero fue un viaje que está realmente ligado a la condición del paisaje de la ciudad: esa relación simbiótica entre paisaje, infraestructura, sistemas naturales, relieve y ocupación humana. Por este camino llegué también a obsesionarme y entender los barrios del norte que popularmente llamamos "las comunas".

Este tema (el de la relación simbiótica entre naturaleza, infraestructura y ocupación humana) no existe en la formación académica tradicional. Siempre se entienden como silos separados. Por ello, poco a poco la práctica me fue llevando a la necesidad forzosa de empezar a unir estas dimensiones en los procesos de investigación, formación y trabajo profesional. Un recorrido que comenzó en los trabajos académicos de la UPB sobre los barrios del norte de la ciudad, siguió en todo lo que hicimos desde la alcaldía con la estrategia de Urbanismo Social, y que hoy conforman el propósito de Urbam en la Universidad Eafit: integrar las dimensiones del urbanismo y el ambiente con los procesos humanos ${ }^{5}$.

Falconi/Infante: Entiendo esta necesidad forzosa de unir lo urbano con lo medioambiental. Sin embargo, Colombia es un país arrugado (montañoso) en toda su extensión y esta manera de entender la relación entre ciudad y naturaleza no es la hegemónica en todo el país. En Bogotá,

$5 \quad$ Alejandro Echeverri trabajó como director de proyectos urbanos durante la alcaldía de Medellín de Sergio Fajardo entre 2004 y 2007. En la universidad Eafit fundó y dirige Urbam, un centro de formación, investigación y proyección social sobre procesos urbanos-ambientales. Para mayor información, ver http://www.eafit.edu.co/centros/urbam/que-es-urbam/Paginas/que-es-urbam.aspx 
para ser puntuales, no existe tal. ¿Qué tanto crees que tiene que ver tu postura como una tradición paisa?

Echeverri: Yo difiero de esta postura. Creo que en Colombia, como en muchos lugares de Latinoamérica, el hecho de que cambiemos forzosamente y en muy poco tiempo de clima, fauna y paisaje al subir y bajar, hace que esa noción de entender nuestra posición con respecto a la naturaleza exista en la cultura general, es posible que no en quienes planifican las ciudades, pero sí en los habitantes.

Seguramente nosotros en Antioquia, que estamos en un territorio prácticamente sin horizonte, y quebrado en su totalidad, tengamos una situación extrema asociada a la segregación y a la tragedia que hemos vivido. La geografía arrugada de Medellín propicia, de cierta forma, no solo la separación social, sino que profundiza las fronteras urbanas y la situación de violencia en la ciudad.

Falconi/Infante: ¿Te refieres a la situación en la que se encontró Medellín en la época de Pablo Escobar?

Echeverri: Exactamente. El problema del narcotráfico de los 80 y 90 generó una crisis de violencia, e hizo visible una batalla de clases sociales, porque el conflicto estaba ligado a territorios muy específicos de la ciudad, a los barrios que nosotros llamábamos como Las Comunas del Norte, que las entendíamos como ajenas a Medellín, que para muchos eran invisibles.

Y, ya como urbanista, ponerte a "hacer ciudad" en un sitio con estos conflictos, y estas condiciones con tensiones físicas y sociales extremas, te pone en un territorio muy singular de trabajo: cómo darle accesibilidad, cómo debería ser el transporte público y la movilidad local, cómo articular todo lo que una ciudad necesita para un hábitat adecuado en estas condiciones ambientales, en suelos y procesos tan dinámicos, con deslizamientos, con fronteras humanas. Es decir, cómo forzosamente debemos cotejar todas estas fricciones que ocurren entre los sistemas naturales y las personas que la habitan.

Falconi/Infante: Entonces, ¿esta crisis significó para ti un punto de inflexión, como profesional, en tu campo?

Echeverri: Sí, esta crisis a mí me cambió y a muchos de nosotros. De hecho, mucho de lo que soy, la razón por la que estamos conversando aquí, es porque forzosamente me puse a estudiar las laderas del norte en esta situación de tensión. En los años 1997 y 1998 comencé una investigación que se llamaba "Siguiendo las huellas del agua, la forma urbana de los barrios en ladera", que era comenzar a narrar y dibujar la geomorfología de la ciudad en su relación 
con las quebradas y cómo sucedía la ocupación en torno a ellas, y empezar a entender sus procesos sociales ${ }^{6}$. Y todo lo que allí sucedía era tan fuerte que nos puso a pensar a muchos, a entender que esos sitios sí eran parte de Medellín, y había que incluirlos como temas de investigación y trabajo.

Falconi/Infante: Es decir, lo interesante es que en tu trabajo te escapas de la visión de muchos en Latinoamérica, me refiero a arquitectos y urbanistas, que solo miran las comunidades de desplazados (los paracaidistas, como dicen en México, los pueblos jóvenes, como le llaman en el Perú, las favelas, en Brasil, comunas en Colombia o ranchos en Venezuela), desde una perspectiva meramente romántica, enalteciendo solo lo vernacular, por un lado, y marginal, por el otro, en que solo recuperan cierto tipo de aspecto formal de estos lugares y lo llevan a la alta cultura, homenajeándolo únicamente de manera formal y terminan por reducirlo al discurso del habitante recursivo. Sin embargo, este no es tu caso. De alguna manera tu trabajo busca comprender otro tipo de aspectos para relacionarlo con el sistema completo que es la ciudad. ¿Podrías ahondar un poco más sobre esta idea?

Echeverri: Sí. Yo estoy de acuerdo con ustedes en que existe esa visión de entender este fenómeno de la informalidad, como que no forma parte plena de la ciudad, como otra categoría. Desde mi punto de vista este es el principal problema hoy.

Yo entiendo el tema de la informalidad y la expansión urbana de estos procesos, sin duda, como grandes retos, pero también como oportunidades, como espacios de aprendizaje muy importantes y que son parte integral de la ciudad. También creo en introducir la noción del tiempo como elemento clave en relación a cómo el hombre habita el territorio y cómo este se va adaptando a sus condiciones. Nosotros hemos encontrado justamente en estos procesos dinámicos, en esta relación en el tiempo entre el habitante y el lugar, el paisaje y la infraestructura, la clave para redefinir políticas y programas, para proyectar nuevas posibilidades.

Falconi/Infante: Claro. Es interesante porque desde los setenta en Latinoamérica, pensemos en Brasil y en el Perú, cuando se visibiliza el fenómeno masivo de la ocupación informal, muchos urbanistas y arquitectos, y los científicos sociales, en general, comienzan a admirar estos lugares y esta gente por su recursividad ${ }^{7}$. Comienza así un romance y una mitologización del

$6 \quad$ Este proyecto, titulado "Los barrios en la ladera: Siguiendo las huellas del agua" fue parte de su tesis doctoral en el Departamento de Urbanismo y Ordenamiento del Territorio de la Universidad Politecnica de Catalunya.

7 Quizá el caso más ejemplar de esta tendencia está presentada en el libro de Hernando de Soto El Otro Sendero, publicado en 1992, en el cual se señala a la informalidad como no solo la consecuencia del problema de la ineficiencia del sistema legal de los países latinoamericanos, sino también una 
poblador de estos sitios, sin que necesariamente signifique hacer el esfuerzo de convertirlo en parte de la ciudad. En tu caso, ¿qué fue lo que aprendiste de esta gente y cómo lo haces parte de la ciudad?

Echeverri: Estoy de acuerdo en que valorar excesivamente lo vernáculo y la realidad de lo informal no es adecuado. Sin embargo, creo que uno tiene mucho que aprender de estos lugares y de los procesos de las personas que habitan ahí. El ingenio que se desarrolla por la exigencia y las limitaciones del lugar es muy valioso. Son estados de consolidación de conocimiento que se refieren justamente a los procesos entre el habitante y el territorio a lo largo del tiempo. Uno puede ver cómo ciertos barrios que fueron muy precarios e informales, en un momento dado, me estoy refiriendo al caso de Medellín, en lo que fue la periferia hace 30 años, son hoy ya barrios consolidados, donde hay bibliotecas y equipamiento, transporte, y estos procesos nuevos se mueven hacia las periferias actuales, más arriba, en la ladera. Es decir, con el tiempo, la informalidad comienza a dejar de serlo y a hacerse parte de la ciudad, mientras tanto, continúa un proceso dinámico de ocupación en los bordes. Es una realidad compleja y extrema en muchas ciudades del sur global.

Falconi/Infante: Es por eso que el término "pueblos jóvenes", como lo llaman en el Perú, es un término casi perfecto en este sentido...

Echeverri: Yo creo que esa es una definición adecuada. Es que la ciudad está hecha de interacción e integración de diferencias y estados muy distintos, que construye este sistema de procesos en el tiempo. Yo entiendo este fenómeno más bien como un lugar que está al inicio de un proceso de ciudad, que va a ir mutando, para bien o para mal, con el tiempo.

A mí lo que me ha parecido bonito es que, en el caso nuestro, hablo en Colombia, pero específicamente en la región donde yo he vivido, ha habido un proceso de diálogo y de construcción, de cambio y consolidación del hombre habitando el paisaje. En un territorio en donde la geografía y los sistemas naturales extremos han sido elementos determinantes.

El problema del hábitat en nuestro caso tiene que trabajarse de una manera muy consciente, en relación con los sistemas naturales. Es decir, no puedes pensar en la construcción de casas, de barrios o infraestructura sin pensar en cómo vas a resolver el problema de la pendiente, cómo vas a solucionar el problema de las aguas, cuál es su geología, cómo vas a entrar a trabajar la accesibilidad y el movimiento de la gente en estos barrios. Y es que hay una presión constante por trabajar estas fricciones que, otra vez, te llevan forzosamente a entenderlos de 
forma holística, lo cual, personalmente, me parece un tema emocionante, que abre un nuevo campo de estudio y de práctica.

Falconi/Infante: ¿Tú llegarías a postular que el estudio de la gente desplazada en general también nos llega a hacer entender el problema del territorio nacional colombiano?

Echeverri: Creo que sí. De hecho, aquí en Medellín, en el Valle de Aburrá, tú podrías hacer casi una descripción de Colombia, haciendo un estudio antropológico de la ocupación del territorio de la ciudad. Muchos de los barrios que han sido ocupados en los últimos 20, 30 o 40 años, informalmente en las periferias, son una imagen de un relato de muchos de los territorios del país. Quiero decir, Medellín es una suerte de collage de comunidades. Los que están ocupando el sector noroccidental o centroccidental vienen del Pacífico cerca al mar, que pertenecen a una cultura y clima diferentes a las comunidades del Oriente, que vienen del Altiplano y que tienen una cultura de agricultura, de floricultura. Entonces, uno va recorriendo estos barrios marginales y encontrándose con distintas formas de ocupación del espacio físico, de cómo usan las casas, distintas historias, formas de comportamiento, música, gastronomía y costumbres que traen distintos lugares del país a la ciudad.

Falconi/Infante: ¿Y qué está por hacerse entonces, cuál es el horizonte que tú planteas a tus alumnos, que está por verse o que está por pensarse en este término de la simbiosis entre persona y habitante de las laderas?

Echeverri: La verdad es que esta pregunta me lleva a esta constante que tenemos en nuestro trabajo, de encontrar a personas que puedan entender este problema desde una visión holística y sean capaces de trabajar en procesos colaborativos cada uno desde su especialidad. Y no es fácil. Este año estamos empezando a trabajar en un pregrado en Urbam/Eafit, que quiere fundarse en esta idea de paisaje y diseño urbano integrado a lo ambiental, a partir de una lógica de pensamiento sistémico. No es sencillo, pero estamos trabajando para construirlo en esta dirección.

Por otra parte, estamos hace algunos años en el proyecto de "Rehabitar la montaña", asociados con Christian Werthmann, que dirige la escuela de formación de paisaje de la Universidad de Leibniz, en Hannover. Este es un proyecto de transformación y de mejoramiento de las laderas en Medellín, específicamente en las quebradas de La Cruz y La Honda, en esta relación de ocupación informal en la parte alta de la ladera en situación crítica de riesgo 
por los deslizamientos, y que está en una ocupación activa porque es de los lugares más jóvenes de la periferia de la ciudad ${ }^{8}$.

Falconi/Infante: ¿Y qué pretende este proyecto?

Echeverri: Lo que pretende este proyecto es construir un proceso de diálogo con las comunidades para entender y dibujar los procesos de ocupación originales. Creemos que la comunidad no puede desligarse de estos procesos de mejoramiento de las laderas y allí estarán muchas de las soluciones. Y trabajamos de forma rigurosa con estudios técnicos y la aplicación de nuevas tecnologías de bajo costo, para abordar los problemas ambientales y de riesgo.

Es un cambio de paradigma para lograr un hábitat sostenible a partir de principios distintos, porque, normalmente, nosotros los arquitectos tendemos a entender el proceso de los proyectos como si fueran tiempos estáticos y como si estuviéramos pensando en imágenes congeladas. En este caso, creo que aquí estamos hablando de una noción dinámica y de cierta incertidumbre, que también es muy bella, porque lo que se hace es establecer líneas de acción en el proceso, pero no se sabe en qué va mutar o terminar. Como estás trabajando en un proceso más abierto y el paisaje tiene, creo yo, ese elemento mágico de estar en constante transformación, y uno no sabe cuáles van a ser los estados futuros, comienza a introducirse la noción del tiempo en relación con el hombre. Creo que hay que aprender todavía a trabajar con esta idea $\mathrm{y}$, en este sentido, cambiar muchas cosas de las que estamos haciendo hoy.

$8 \quad$ Las quebradas de La Honda y La Cruz son dos quebradas del lado oriental del valle del Aburrá, que se extiende a lo largo del río Medellín, y en donde está asentada la ciudad del mismo nombre. Para mayor información sobre este trabajo, ver: Claghorn, Orsini, Echeverri Restrepo y Werthmann (2015). 


\section{ENTREVISTA A ERNESTO BILBAO}

\section{Quito, Ecuador}

Falconi/Infante: Tomando en cuenta tu experiencia en la transformación del exaeropuerto Mariscal Sucre y contextualizándolo en el paisaje latinoamericano, ¿cómo te interesó el tema del paisaje como arquitecto?

Bilbao: En Latinoamérica no tenemos la carrera de Arquitectura del Paisaje como pregrado, por lo que todo comenzó por iniciativa propia. Empecé a curiosear y a desarrollar temas asociados al paisaje aún siendo estudiante, lo que probablemente derivó en que terminara diseñando mi tesis en el Parque Metropolitano de Quito, que es una reserva boscosa que se inauguró mientras yo aún estudiaba9. Este caso es interesante porque persisten unas heridas muy fuertes en los cerros asociados al parque por la acción de una antigua cantera que había en el sitio. Yo empecé a trabajar en torno a estas heridas, a su presencia y su afectación paisajística, por lo que terminé proponiendo en mi tesis un edificio que trataba de generar algún tipo de solución respecto a estas cicatrices.

Falconi/Infante: ¿Por qué lo llamas "herida"?, ¿por qué no qué no llamarla arteria, vena o extensión?

Bilbao: Quizás el cómo lo nombro ha sido más bien un proceso. Cuando estaba desarrollando mi tesis, simplemente les llamaba "corte de montaña", pero, cuando empecé a involucrarme con temas de paisaje, me sorprendió mucho un número de Paisea que se llama "Cicatrices" y creo que fue la primera vez que vi los "cortes de montaña" de esta manera: como una herida en el paisaje, como si hubiéramos cortado con cuchillo o destapado lo que hay debajo de él ${ }^{10}$.

Es muy impresionante pensar en el Parque Metropolitano como un gran bosque, porque este tiene una topografía muy dramática con cortes de 20, 30 y hasta 50 metros de altura, y con una pendiente entre 70 y 90 grados. Además, es un lugar visible desde muchos lugares de la ciudad y que está junto a la nueva Avenida Simón Bolívar que es de las perimetrales más importantes de la ciudad. Esta situación me inquietaba muchísimo porque definitivamente te hace abordar el territorio como algo intervenido, que ya no es natural: está humanizado, es un espacio público. De aquí nace la cuestión de la herida y la cicatriz, y así lo he podido aplicar en muchos proyectos. En el Parque Bicentenario, por ejemplo,

$9 \quad$ La ciudad de Quito tiene tres parques metropolitanos, dos en el norte (Guanguitagua y Rumipamba) y uno en el sur de la ciudad (del Sur). La tesis de grado de Bilbao (1998) en la Universidad San Francisco de Quito fue una propuesta para un hotel en el Parque Metropolitano de Guanguiltagua.

10 Ver Paisea, n. ${ }^{\circ}$ 16, http://www.paisea.com/revista-paisea/016-cicatrices/ 
que fue un sitio transformado paulatinamente en una gran infraestructura que luego se abandonó, también se convierte en una suerte de vestigio de esa interacción entre el hombre y la naturaleza'11.

Falconi/Infante: Uno de los precedentes más reconocidos en transformación de infraestructuras de este tipo es el aeropuerto de Tempelhof en Berlín, ¿qué tanto lo tuviste en consideración? Y en relación con temas de paisaje, ¿qué tipo de propuesta paisajística estás proponiendo para la ciudad de Quito con respecto a ese nuevo parque?

Bilbao: Creo que el referente de Berlín es importantísimo, pero, la verdad, yo no lo tomé como referente tan fundamental en este contexto. Para mí, el Downsview Park, por ejemplo, sí es un paradigma y una nueva manera de ver los proyectos de paisaje en este contexto, por lo que fue fundamental como referencia, principalmente por dos razones: en primer lugar, se introduce el concepto de "tiempo" como un elemento vital de diseño del paisaje ${ }^{12}$.

Ver cómo varias de las propuestas incluyen el tiempo porque consideran que para lograr transformar esta antigua base aérea se necesitaban fases de implementación es interesante, porque incluso la forma de representación del paisaje cambia, se comienzan a generar gráficas, dibujos y propuestas en donde, etapa por etapa, se van transformando estas infraestructuras y se va previendo cómo el paisaje puede consolidarse en el tiempo. En segundo lugar, introducir el marco temporal permitió la posibilidad de generar tipologías de paisaje respecto a varios factores: acumulación de agua, sitios de remediación ambiental de manera paulatina, etc. En ese sentido, la experiencia del Downsview Park me pareció sumamente valiosa. En contraste, si uno revisa el concurso del Parque del Lago de 2008, la aproximación de las propuestas al sitio es muy diferente, ya que la gran mayoría lo hizo de manera formal, casi compositiva: este lago desaparecido por la acción de una infraestructura se entendía como un espacio vacío sobre el cual se construiría otro lago, un pequeño bosque, una pradera, un centro de convenciones, etc ${ }^{13}$. Es decir, como un sitio que podía pensarse desde cero; no entendían el espacio ni su valor por lo que había sido. Mi propuesta, en cambio, no era compositiva únicamente, sino, más bien, era una estrategia en la que se podía, con base

11 Como es sabido, el Parque Bicentenario es una gran área verde de carácter público en Quito que reutilizó el sitio del antiguo aeropuerto de la ciudad. Fue inagurado el 27 de abril de 2013, y hasta la actualidad constituye el área verde más grande de la ciudad.

12 Downsview Park es un parque público de carácter federal en la zona de North York, en Toronto, Canadá, que se creó al transformar una antigua base de la Real Fuerza Aérea de Canadá en 1999. Es considerado como el primer parque nacional urbano del país y fue diseñado en un inicio por Bruce Mau y Rem Koolhaas, aunque las autoridades dejaron de lado el diseño de "Tree City" ("Ciudad Arbol”), propuesto por los diseñadores pocos años después de su inauguración. (la recuperación del exaeropuerto Mariscal Sucre de Quito) al norte de la ciudad en 2008-2009. 
en el tiempo, establecer una serie de fases de implementación que se irían consolidando en algunas décadas. Por eso, la imagen final de este proyecto es más una especie de anhelo al cual queremos llegar, que una manera rígida de llegar exactamente a lo propuesto.

Falconi/Infante: ¿Y cuál es ese anhelo?

Bilbao: La recuperación ecológica del sitio original. En la propuesta hay dos paisajes predominantes: uno de bosque húmedo y otro de estepa. Estos corresponden a los pisos vegetacionales que existían originalmente. El parque es justamente el punto de conexión entre ellos. Por ello, mi propuesta se planteaba la pregunta de si es posible recuperar estos dos paisajes dadas las condiciones ecológicas reales del sitio. Había que determinar qué tan posible era recuperar o volver a este estado natural con base en una serie de fases de tiempo o de implementación.

Falconi/Infante: A pesar de que nunca se construyó el Downsview Park, sí fue el que puso en el tapete la cuestión del tiempo y la tipología, lo que comenzó a ser una constante en los proyectos de paisaje contemporáneos. Proyectos como el High Line, el Freshkills Park, entre otros son detonantes en una corriente de arquitectura del paisaje que incorpora el proceso como clave en las propuestas ${ }^{14}$.

Bilbao: Así es. Por ello, la propuesta es tan interesante. El hecho, por ejemplo, de que en la propuesta gráfica de Rem Koolhaas aparezcan "círculos" muestra que la aproximación no es formal, sino que se enfoca en la estrategia que plantea una forma de operar sobre el lugar.

El concebir el paisaje como urbano empieza a aparecer inminentemente en el concurso del Parc de la Villette ${ }^{15}$. En ese sentido, yo creo que Tempelhof es interesante, para volver a referirme al inicio de la entrevista. En Berlín, se hizo una consulta ciudadana para saber qué hacer con este parque y se decidió mantener la pista como tal y eso responde a una forma de entender el espacio público desde una sociedad en específico, como es la alemana. En el caso quiteño, cuando se abrió el exaeropuerto como parque, muchos se lanzaron contra el alcalde y preguntaban: “¿y dónde está el parque?”, “¿dónde están

14 High Line y Freshkills Park son dos parques de la ciudad de Nueva York que han reutilizado áreas antes antiguamente asignadas a otras funciones de la ciudad. Abierto en 2009, High Line reutilizó un poco más de dos kilómetros de una antigua vía férrea elevada en la zona suroeste de Manhattan y es ahora considerado una atracción turística de la ciudad. Freshkills Park, en cambio, está siendo construido sobre un antiguo relleno sanitario en Staten Island, uno de los suburbios de la ciudad, y recién estará terminado en su totalidad en 2035, cuando se convertirá en el segundo parque más grande de la ciudad de Nueva York.

15 Ubicado en el noreste de la ciudad, el Parc de la Villete es el tercero más grande de París, y es conocido por ser sede de un gran número de instituciones culturales de la ciudad. Fue diseñado entre 1984-1987 por el arquitecto suizo-francés Bernard Tschumi, quien tuvo como asesor al filósofo Jacques Derrida. 
los árboles?”, “¿dónde está ‘el verde’?” “¿dónde está todo?”. Y es que en una sociedad ecuatoriana o latinoamericana es difícil incluir esta nueva tipología de paisaje. Por ello, fue necesario empezar a hacer un trabajo de comunicación para que los ciudadanos entiendan lo que significaba el proceso del parque, cómo se desarrollaría en el tiempo. Solo después de esta campaña la gente comenzó a aceptarlo de una mejor manera. Pero ahí volvemos a una pregunta fundacional que es: ¿qué entendemos por paisaje y qué no se entiende por paisaje?

Falconi/Infante: ¿Podrías profundizar un poco más en el proceso social que se desarrolló en el proyecto?

Bilbao: El aeropuerto cerró su operación en febrero de 2013 y en abril de ese mismo año fue abierto como Parque Bicentenario por el alcalde Augusto Barrera. El día de la apertura llegaron al sitio 300000 personas, lo que a mi parecer es un gran evento para una ciudad como Quito. Parecía magnífico lo que estaba sucediendo, se sentía fenomenal para los ciudadanos utilizar una pista que había sido para los aviones. La gente empezó a utilizar ese parque para muchísimas actividades, los quiteños empezaron a hacer común el aprender a andar en bicicleta ahí, montar en patines, lo usaban incluso para bicicletas de ruta, aeromodelismo, parapente y un sinfín de actividades que antes no nos habríamos imaginado. Pero, claro, esto pasó después de varios meses. Al comienzo la gente fue muy dura contra el alcalde porque no entendían dónde estaba el parque, y ahí es donde está ese cambio de paradigma que se tiene que dar en Latinoamérica: ¿qué es un espacio público?, ¿es solo árboles perfectamente plantados o puede ser una infraestructura como está?

Falconi/Infante: ¿Te refieres a que el entendimiento de "lo colectivo" es diferente en cada cultura?

Bilbao: Sí. Además que en Latinoamérica los recursos son extremadamente limitados, lo que, sumado a los tiempos de las administraciones políticas y al imaginario de parque que se tiene como ciudadanos, hace mucho más difícil el avance en estos proyectos. El alcalde tuvo que salir a explicar por qué todo esto era beneficioso para la ciudad, pero también por qué había zonas confinadas a remediación ambiental que no podían utilizarse inmediatamente y requerían tiempo, además de recursos y procesos que eran incluidos en la propuesta.

Sin embargo, como les decía, con el uso y el "regalo" de tener, de pronto, 126 hectáreas de nuevo espacio público en la ciudad, la gente empezó a aceptar esta multiplicidad de nuevos usos que ofrecía el sitio. Es cierto que siempre ha habido una nostalgia por lo verde en este contexto, pero creo que se debe a que el quiteño está acostumbrado a los parques que tenemos desde siempre en la ciudad: el parque La Carolina, el parque El 268 Ejido, la Alameda, las estribaciones de la cordillera del Pichincha, el Parque 
Metropolitano del Sur, la cordillera Oriental con el Parque Metropolitano, entre otros $^{16}$. Hay una concepción del paisaje quiteño como "verde" y por esto es que, finalmente, "el verde manda" en la concepción de los ciudadanos en torno a este tema. Es lógico que la reacción inicial de un parque con una pista de aviones en medio haya causado un choque fuerte para todos, pero poco a poco se empezó a aceptar y a generar varios usos interesantes de este. Además se convirtió en un sitio único donde se pueden promover eventos masivos, como lo fue la visita del papa o el concierto de Metallica (banda de rock), antes no era posible hacer algo así en esta ciudad ${ }^{17}$.

Falconi/Infante: Entonces, ¿cuál es tu propuesta con respecto a este lugar?

Bilbao: Creo que hay que resaltar las dificultades políticas que suponen un proyecto de estas características, sobre todo con los tiempos que requieren. En ese sentido, que el parque ya exista como parque y no como sitio abandonado ya es un avance, considerando que han pasado varias administraciones. Creo que el haber conseguido proponer estas fases de implementación y las tipologías de paisaje para recuperar ecológicamente el sitio ha sido fundamental para el correcto desarrollo del parque en el tiempo. Es interesante que este tipo de estrategias sean aplicables a cualquier proyecto de paisaje, ya sean estas para 126 hectáreas o para algún otro. Es muy lindo cómo estos proyectos finalmente se conectan con el paisaje regional en términos ecológicos, en términos operacionales, funcionales y de paisajes vinculados con la ciudad misma. Es decir, el comprender que un proyecto no se mira únicamente desde el perímetro del sitio a intervenir, sino que debe entenderse sistemáticamente con todas las variables: la ciudad, el paisaje, la ecología, la cultura, etc. Creo que esa es una lección que me quedó luego de la evolución de todo el tema del Parque Bicentenario. Un tema interesante es que, al entender sistemáticamente los proyectos de paisaje, se pueden generar sinergias entre varios procesos urbanos en construcción. Ahora, en Quito, por ejemplo, se está construyendo el metro soterrado y nosotros estamos aprovechando esa tierra para generar las topografías del Parque Bicentenario. Esto es fascinante porque se logran establecer vínculos entre infraestructuras urbanas y se producen coyunturas hasta en términos de sostenibilidad de proyectos.

16 Como se sabe, Quito es una de las ciudades capitales latinoamericanas con mayor número de áreas verdes por habitante y parques muy emblemáticos. En el centro de la ciudad se erigen La Alameda y los parques El Ejido y La Carolina, al sur se encuentra el Parque Metropolitano del Sur y al norte, el Parque Metropolitano Guanguiltagua, el parque urbano más grande de América del Sur.

17 La visita del papa Francisco a la ciudad de Quito se realizó entre el 5 y el 8 de julio de 2015. La misa en el parque se efectuó el 7 julio, donde se congregaron más de 900.000 personas. La banda de rock Metallica, por su parte, se ha presentado dos veces en el parque, la última vez fue el 29 de octubre de 2016, y hubo más de 35.000 personas. 
Falconi/Infante: Y con este parque, ¿cómo ves a Quito enraizada con su paisaje?

Bilbao: Yo creo que Quito tiene una gran ventaja frente a otras ciudades y es porque está rodeada de un entorno paisajístico impresionante: tener el volcán Pichincha al oeste, las montañas y una condición de cuenca bien delimitada, etc. Esta condición es fundamental para el quiteño, y creo que ejemplos como el Parque Bicentenario, que incluyen redes ecológicas articuladas a otros sistemas, son una reflexión importante para el paisaje latinoamericano contemporáneo, para la investigación en estos temas, para la recuperación del paisaje y la transformación de infraestructuras urbanas.

Falconi/Infante: Existe una falta de infraestructura paisajística no solo en Quito, sino en todas las ciudades andinas que son de valles. Pareciera que todavía existe una relación con el paisaje a nivel muy estético, ¿no?

Bilbao: Estoy absolutamente de acuerdo. Creo que hoy se entiende la ciudad de Quito, tanto desde la práctica profesional como desde las escuelas de arquitectura, en sentido longitudinal y urbano únicamente, como una mancha separada de los cerros que existen alrededor. Si bien creo que ya existe el entendimiento de que los cuerpos verdes que están dentro de la ciudad deben conectarse en sentido longitudinal (norte sur, en el caso de Quito) a una red regional mayor, todavía esta idea es muy incipiente. Hace un tiempo estuve a cargo de un proyecto del Municipio para el sur de Quito que justamente lo que buscaba era generar conexión entre la ciudad sentido contrario, es decir, occidente con oriente, procurando incorporar todos los grandes elementos paisajísticos que tiene el valle con los de las cordilleras del volcán Pichincha. Se buscaba hacer una gran red interconectada en términos "verdes", pero también de infraestructura, de cultura, de movilidad, etc. En definitiva, articular todos los elementos para la concepción de un nuevo plan de red verde urbana para el sur de Quito. Estuve algún tiempo desarrollando este proyecto, y que el Municipio haya tenido la iniciativa de hacerlo es también una gran señal de cómo en la ciudad nos estamos preocupando por estos temas.

Falconi/Infante: $Y$, con respecto a este despertar en las temáticas de paisaje desde la ciudad, ¿crees que la política ha tenido influencia? Estoy pensando específicamente en los primeros años de un correísmo que utilizó las alzas del petróleo para generar una gran cantidad de plataformas de transformación para la ciudad y el país en general ${ }^{18}$.

18 Como se sabe, el presidente Rafael Correa gobernó Ecuador por tres períodos consecutivos (20072017), que estuvieron marcados por el boom de las materias primas y el alza del petróleo, lo cual considerable en la inversión en infraestructura a lo largo de todo el país. 
Bilbao: Esta pregunta es muy interesante en nuestro contexto. Creo que la autoridad y la política están muy ligadas a la práctica del paisaje y del espacio público. En el caso de Correa, creo que ha tenido elementos positivos y negativos. Por el lado positivo, por primera vez en la historia del país hubo iniciativa por generar espacio público o paisaje desde la entidad pública de una manera fuerte. Digamos, la promoción de desarrollo de proyectos de parques era una de las banderas del gobierno anterior. Esto, sumado a la coyuntura de la bonanza económica, hizo que prácticamente siempre hubiese proyectos de arquitectura desde lo público hasta lo privado, pero sobre todo desde lo público. Y muchos se hicieron bien y esto es fantástico para el país. Sin embargo, hubo ciertos proyectos que no aprovecharon la situación por la simple cuestión del tiempo. Los tiempos políticos y los técnicos de los proyectos generalmente son muy distintos, por lo cual tratar de alinear las fases de diseño para convertirlas en banderas de gobierno es un tema sumamente recurrente y, en el caso de muchos proyectos en el Ecuador, resulta que se hicieron con apuro y resultaron mal y esto es, simplemente, un fracaso. Hoy estamos en una nueva realidad de país y tomará mucho tiempo para que podamos estar en una situación similar. Sin embargo, creo que esa etapa ha servido para aprender, para valorar las obras que son para todos, para poder revisar estas ideas y adaptarlas al contexto actual. Creo que el paisaje, en este sentido, ya es un tema transversal en las universidades, y que va a cambiar seguramente la forma en que propongan proyectos las nuevas generaciones.

Falconi/Infante: ¿Tú crees que ya se ha logrado, de alguna manera, una tradición paisajística con futuro para las siguientes décadas en el Ecuador?

Bilbao: Yo estoy convencido de que esto ya está sucediendo. Como comentaba, creo que el Parque del Lago marca un paradigma en la práctica del paisaje en el Ecuador, así como Downsview Park lo fue en su momento para el escenario internacional. Soy muy optimista porque creo que desde entonces la gente se ha interesado muchísimo más por el paisaje de la manera en que la estamos conversando aquí. No quiero parecer celebrándome, sino que simplemente pienso que luego del proyecto ha habido un cambio en la aproximación a la materia. Mucha gente se ha ido a estudiar maestrías en Paisajismo e incluso se están abriendo programas aquí referentes al tema, lo cual es inédito para el país.

Falconi/Infante: Esto es más bien una sensación que una pregunta, pero ¿crees que el paisaje de Quito y de todas estas ciudades andinas que no pueden darle la espalda a una geografía absolutamente presente hace que se piense la arquitectura "más allá del lote" y tenga, por defecto, que relacionarse con "algo más"? 
Bilbao: Absolutamente. Pienso que vivir en condiciones de paisaje tan fuertes es una condición que transforma a la arquitectura. No podemos no reconocer el paisaje. El volcán, la ladera, el corte de la montaña, el río y también la migración de aves, el viento, la especificidad de la vegetación propia, etc., son una infinidad de aspectos que nos hacen ser y responder de una manera estrictamente dirigida al lugar donde vivimos. Tenemos que simplemente seguir abriendo los ojos y abriéndoles los ojos a los demás mucho más allá del objeto arquitectónico en sí. Tenemos que aprender a conocer nuestro territorio y ser capaces de hacer eso maravilloso, que es articularlo con nuestros diseños.

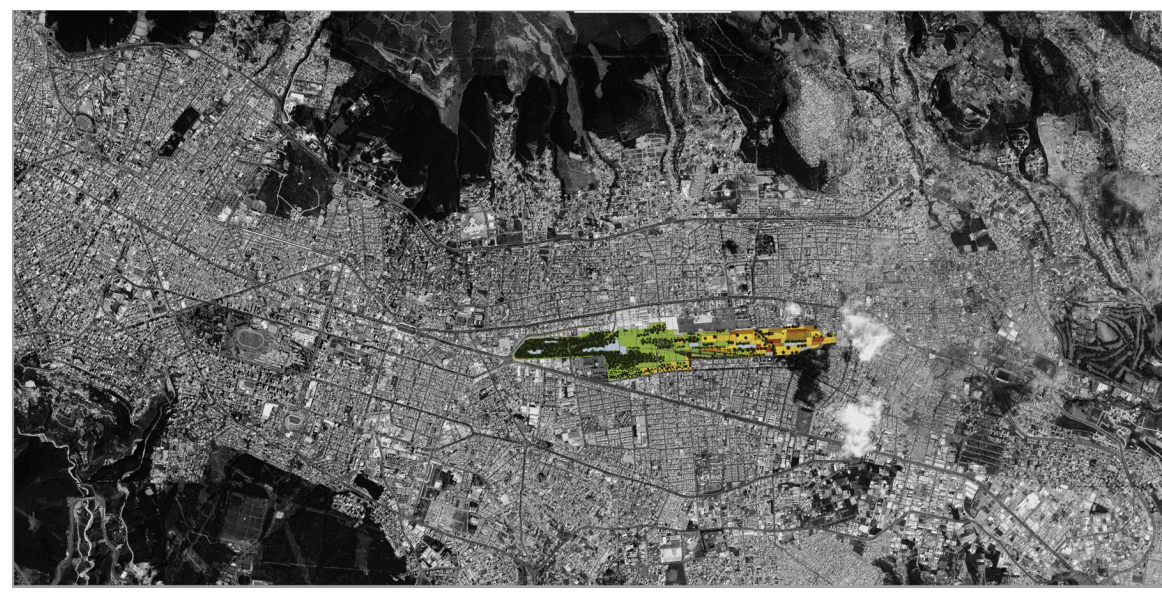

Figura 2. Proyecto Parque Bicentenario, en el paisaje del norte de Quito (O). Ernesto Bilbao. 

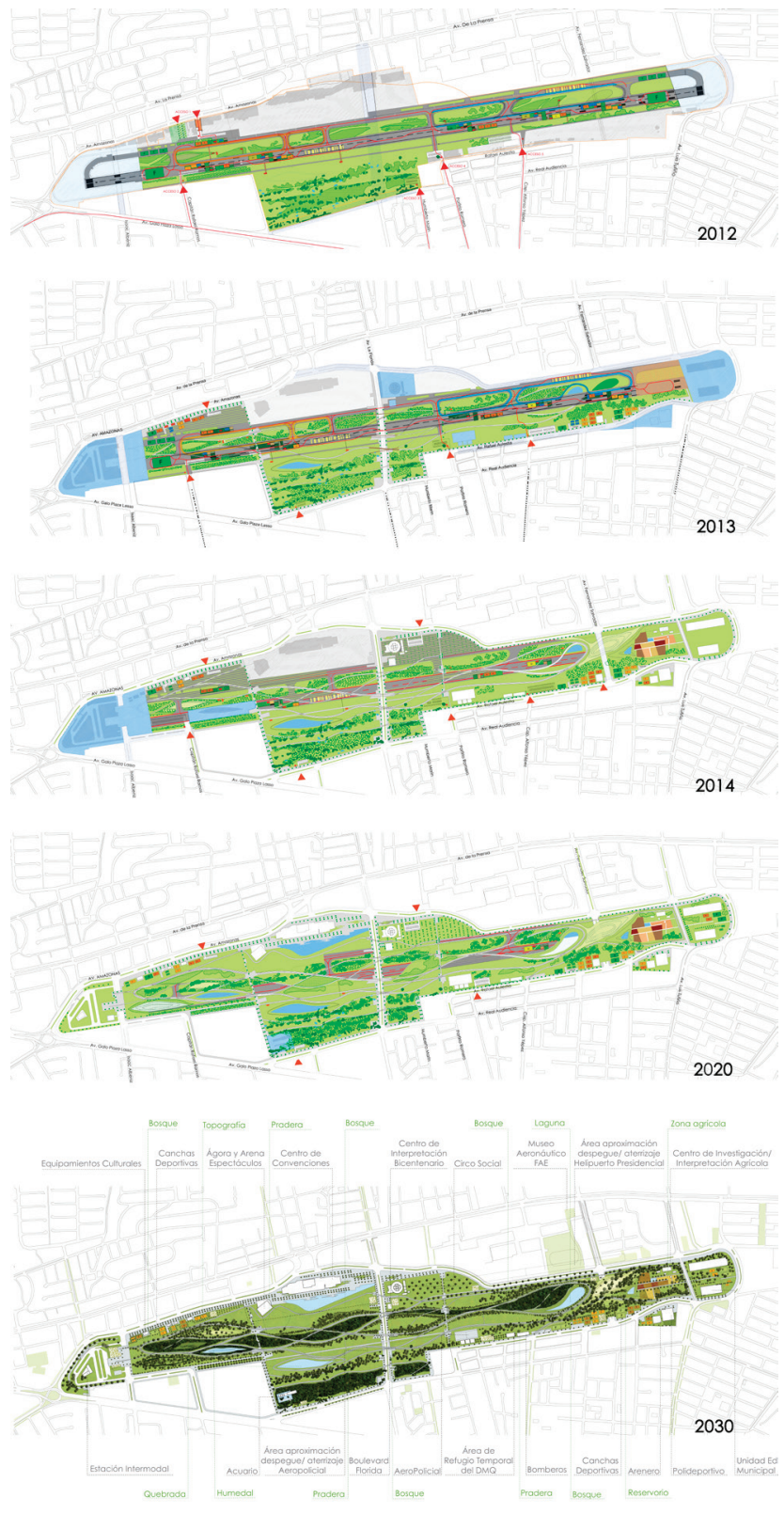

Figura 3. Fases del proyecto del Parque Bicentenario de Quito (O). Ernesto Bilbao. 


\section{ENTREVISTA A JEAN PIERRE CROUSSE}

\section{Lima, Perú}

Falconi/Infante: ¿Cómo ves la paisajística peruana en términos arquitectónicos? Entendemos que tu libro es uno de los primeros esfuerzos en torno a este tema por lo que se abre la pregunta acerca de qué significa el paisaje peruano en la actualidad, ¿qué tipo de relevancia tiene?

Crousse: Hay dos cuestiones que yo planteo. En primer lugar, el paisajismo peruano existe en términos históricos y el libro está hecho para confirmarlo: hay una mirada consciente sobre el paisaje y hay una construcción colectiva y permanente de este por medio de la historia. En segundo lugar, creo que, en la actualidad, no existen muchos ejemplos hechos por profesionales que sean conscientes de esta noción de paisaje peruano. De este modo, el libro intenta dar cuenta de este estado de la cuestión en Perú con respecto al paisaje, y trata de articular visiones que ya han explorado otras disciplinas (la arquitectura, la geografía y la arqueología, entre otras) en torno a estas temáticas para proveer herramientas arquitectónicas que comiencen a comprender el paisaje de manera más integral. No creo que el libro ofrezca una respuesta a esa necesidad de empezar a teorizar el paisaje peruano, pero sí lanza algunas preguntas y preocupaciones por comenzar a entender el paisaje desde la arquitectura. En Perú, no hay una sola facultad que enseñe o reflexione sobre este tema como una preocupación integral (salvo la reciente iniciativa en Tacna) ${ }^{19}$. Si bien existen programas que reflexionen en torno a temáticas tangentes al paisaje, no lo hacen sobre el paisaje mismo.

Falconi/Infante: Entonces, ¿cómo te interesó reflexionar en torno al paisaje a ti personalmente si es que no existía un diálogo importante sobre este en Perú? ¿Con qué tipo de preocupaciones venías para comenzar a mirar al paisaje?

Crousse: Yo creo que hay dos aspectos que originan mi interés por este tema. El primero tiene que ver con mi amor por lo precolombino que me fue inculcado por mi padre, también arquitecto, lo cual nos llevó a realizar muchos viajes dentro de Perú antes de la época del conflicto armado ${ }^{20}$. Este fue un punto importante, pero que estaba latente en mí hasta que Sandra

19 La maestría en Arquitectura Paisajista de la Universidad Privada de Tacna ha sido creada recientemente. Para mayor información, ver http://postgrado.upt.edu.pe/postgrado/maestria/ maestria-en-arquitectura-paisajista/

20 Como se sabe, Perú sufrió un conflicto interno entre mayo 1980 y los finales de la década de los noventa -el final del conflicto es siempre un poco incierto- entre las Fuerzas Armadas y dos grupos insurgentes, Sendero Luminoso y Movimiento Revolucionario Tupac Amaru. La Comisión de la Verdad (2001-2003) concluyó que fueron casi 70.000 los muertos por el conflicto. Para más información, ver https://www.cverdad.org.pe/ 
y yo nos fuimos a Europa a estudiar y a trabajar ${ }^{21}$. Y aquí viene el segundo aspecto: yo creo que esa distancia con nuestro medio me hizo dar cuenta de muchas cosas que no se me hacían evidentes viviendo en Perú. El desierto, por ejemplo, comencé a entenderlo como un paisaje y no como un vacío, que es como comúnmente lo entendemos en Perú y como nos lo habían enseñado. Y, desde el momento en que el desierto se entiende como paisaje, los proyectos que allí se diseñan deben responder a las consideraciones espaciales, climáticas, etc., específicas para este contexto. Esto lo entendían las culturas precolombinas, pero esta sensibilidad se fue perdiendo luego de la conquista europea. Parece que el interés por el paisaje nació cuando no estaba inmerso en él. Pareciera que la distancia que uno necesita para apreciar el paisaje, en mi caso, se trató más de una dimensión temporal que una de longitud: los 16 años que estuvimos fuera resultaron como un caldo de cultivo para empezar a descubrir lo que esto significaba, e incluir conscientemente estas variables en las primeras oportunidades de proyecto que tuvimos en Perú (primero desde Francia y luego aquí). Desde ese momento, comenzamos a explorar las posibilidades que tiene la arquitectura en este paisaje y a convencernos de la necesidad de entenderlo. Sandra, por su lado, también ha hecho algunas investigaciones en torno al tema que nos han llevado a plantearnos más preguntas. Al final de cuentas, utilizamos este conocimiento para aplicarlo en nuestros proyectos, lo que levanta nuevas interrogantes que a su vez exigen nuevas indagaciones.

Falconi/Infante: Es decir, nada de esto fue programático, sino simplemente una cuestión intuitiva que fue tomando forma por medio de la práctica a través de los años. Y fue la confrontación con tu paisaje primario -el desierto costero- lo que detonó esta línea de reflexión. Por otro lado, tu libro nos sitúa en la tradición prehispánica como punto de partida para el paisaje peruano. De alguna manera, para entender el paisaje en Perú, debemos confrontarnos necesariamente con la historia precolombina. Es decir, el paisaje peruano siempre está mediado por un paisaje histórico.

Crousse: Sí, con respecto a nuestro interés por el paisaje, fue la confrontación proyectual con el desierto lo que empujó a que esta intuición que venía desarrollándose desde la distancia se pudiera plasmar en un proyecto real. Al interesarnos por el desierto, comenzamos a entender que este no puede comprenderse cabalmente si no lo vemos de manera territorial y, para que esto suceda, debemos ver la historia. El paisaje no es solamente lo que está delante de nuestros ojos. Por medio de la investigación -que no es estrictamente histórica-, comenzamos a entender el paisaje peruano como 
metavisual. Esto es más o menos lo que planteo en el libro: el paisaje no solamente es lo que se ve, sino lo que se entiende mentalmente y lo que podemos reconstruir en la mente como paisaje. Esto en Perú se da por la verticalidad de los Andes y su posición en una latitud tropical. La altitud determina las características del paisaje. A mí me parece fundamental entender que el paisaje peruano se rige por altitud y no latitud, es decir, que los puntos cardinales en un plano no son tan importantes como la comprensión por medio de la sección. Es este corte territorial el punto de conexión que nos permite entender el paisaje y relacionarlo con la arquitectura. Desde aquí es que hemos desarrollado nuestros proyectos.

Nuestros primeros trabajos acerca del paisaje peruano fueron unas casas de playa que desde un inicio estuvieron pensadas como una capa más dentro de lo complejo que puede ser el lugar. En este sentido, nos alejamos del tradicional binomio "objeto arquitectónico-encuadre" para entender la relación con el paisaje como un conjunto de capas. Quisimos alejarnos de la idea de que la arquitectura es solo un objeto posado en un paisaje, en la que únicamente hay una relación binómica (arquitectura y encuadre en el paisaje o arquitectura modificando el paisaje), y comenzamos a reflexionar en cómo la arquitectura se despoja de su condición de objeto para convertirse en una capa que se añade a muchas otras. Por eso es que planteamos que el paisaje hay que entenderlo desde la historia y que a esta se le añaden muchas otras capas superpuestas, conformadas por la geografía, las condiciones ecológicas, las intervenciones humanas previas, etc. Nuestro reto es cómo trasladar todo este conocimiento a la arquitectura, entendida como un microcosmos del paisaje. En todos nuestros proyectos de casas, por ejemplo, buscamos que la casa misma explique o contenga los elementos esenciales del paisaje. La Casa Equis, que fue la primera en la cual ensayamos esto, tiene una sección del acantilado en el que uno descubre casi una especie de microsección de lo que va desde el Pacífico hasta los Andes. Es decir, es una secuencia que va desde una piscina que está hacia el oeste hacia un único árbol dentro del recinto de la casa. Así, la casa condensa enormes dimensiones, contiene un nuevo espacio reproduciendo esa sección (desde el agua hasta lo fértil) y genera este microcosmos. Creo que esta idea fue evolucionando con los años, y eso se puede ver en el Lugar de la Memoria (2010-2015), por un lado, y en el edificio universitario en Piura, por otro (2015-2016).

Falconi/Infante: El Lugar de la Memoria nos gusta mucho porque hay una suerte de orificio dentro del territorio, por lo que tiene una connotación arqueológica muy evidente que lo hace muy afín a la tradición peruana. Quizás lo único en lo que tenemos reparos es en esa coreografía que el espacio mismo propone y por el cual se recorre la tragedia terminando siempre en una azotea 
luminosa que da al horizonte del mar, lo cual es un recurso muy recurrente en muchos museos memoriales. El problema aquí es que el recorrido espacial propone una lectura en donde se termina en una reconciliación. Y es complicado pensar que ese museo propone una reconciliación por medio de este recorrido. ¿Cómo ves este proyecto?

Crousse: Vamos por partes. Es cierto que el proyecto tiene una parte arqueológica, si se quiere, en el sentido de investigar o usar de referencia lo prehispánico como una suerte de banco de estrategias proyectuales para lugares y paisajes. Pero es más interesante entender el edificio como parte de la geografía del lugar más que como un objeto situado sobre él. Estábamos en un sitio privilegiado de Lima, justo en el lugar que define el modo en que Lima se encuentra con el océano, esos 50 metros de acantilado que existen entre la llanura aluvial y las playas y el mar. Diseñar algo aquí es excepcional y fue justamente esta condición la que marcó el inicio del proyecto. El lugar tenía una serie de dificultades que debían de ser potenciadas a pesar de disponer de un presupuesto limitado, porque, como saben, el dinero fue una donación de gobiernos extranjeros.

Así, comenzamos a analizar las lógicas topológicas y económicas posibles en el lugar. Este sitio es una de las rutas para bajar a la playa y, en su construcción, se creó una gran hondonada que fue luego rellenada, por lo que el suelo portante quedó a una treintena de metros de profundidad. Entonces, debíamos diseñar el edificio de la manera más eficiente posible para reducir los altos costos que esto iba a tener. De esta manera, la estrategia fue pegarnos al acantilado y hacer un edificio compacto para economizar en el número y la profundidad de los pilotes. A continuación, buscamos utilizar la misma lógica de esta sucesión de farellones y quebradas para hacer del edificio una especie de farellón artificial -la entrada se realiza por una quebrada entre el farallón "natural" y el "artificial", haciendo siempre la salvedad de que aquí ya nada es realmente "natural", ya que toda la línea costera ha sido intervenida.

Por otra parte, introdujimos el programa arquitectónico como problemática. Es aquí donde el partido de edificio compacto y pegado al farallón hizo posible proponer una amplia explanada o "cancha" que propusimos como espacio público porque justamente -y en eso estoy de acuerdo contigo- la reconciliación no se da solo a través de una muestra. La muestra lo único que hace es hacernos reflexionar sobre el pasado. La reconciliación se da solamente con el reconocimiento del "otro distinto". Esta plaza pretendía, justamente, ofrecer ese espacio de encuentro y diferenciarlo del recorrido de la muestra. En otras palabras, la explanada respondía a un problema del sitio y ofrecía una respuesta al cometido del edificio como institución. Pero el gran problema eran los 300 metros que separan la parada de bus más cercana de la 
entrada al edificio. El espacio disponible que teníamos para unir esta plaza y el museo a la ciudad era de menos de dos metros de ancho, atenazados entre el cerco del estadio municipal y la bajada vehicular a la playa.

Estábamos, pues, frente a un problema serio para un edificio público que debe ser fácilmente accesible, abierto a la ciudad, etc. Así, decidimos utilizar esta distancia a nuestro favor para introducir la noción de tiempo en el recorrido, generando las condiciones necesarias en el público para apreciar la muestra. Empezamos reflexionando con el fotógrafo Roberto Huarcaya en torno al rol de la fotografía documental en un momento en que las herramientas digitales debilitan su carácter testimonial (cualquier imagen puede ser "editada"). Un recorrido performático permite ponernos en la condición de apreciar su valor testimonial y transmitir eficazmente cierto contenido. Para nosotros, era fundamental que el espectador se aleje de lo cotidiano y se introduzca en la apreciación de un contenido museográfico que no es agradable de ver y que nos avergüenza como seres humanos. Por ello, decidimos hacer el recorrido bajando por la quebrada e introducirnos a este espacio intermedio que no es la ciudad y tampoco la playa. Concuerdo en que este recorrido ascensional puede ser percibido como algo maniqueísta, al terminar en una terraza frente al horizonte y el mar, pero, para nosotros, era importante culminar el recorrido en un lugar de silencio, más contemplativo, después de pasar por el contenido de la muestra, y que el circuito empiece y termine en la ciudad, y no en la boutique y el hall, como sucede frecuentemente en los museos. Este lugar marca una última pausa y ofrece un tiempo de preparación para regresar al cotidiano.

Falconi/Infante: Sin embargo, el museo aún sigue siendo un espacio contestado. Que no ha sido aceptado de manera total por la gente, está en una suerte de limbo ideológico.

Crousse: Además, está en riesgo permanente de cerrarse. La reconciliación pendiente es la clave en este proceso. Este es el único museo de la memoria en Latinoamérica que no ha sido construido ni apoyado por el Estado, lo cual hace una gran diferencia, pues se convierte en un sitio de resistencia y no de celebración o conmemoración, como sucede normalmente. Tenemos un lugar de memoria que fue hecho "a pesar del Gobierno". La otra duda es: ¿por qué hacer un museo desarraigado de los lugares que vieron ocurrir los hechos que muestra? Pensamos mucho en eso cuando hicimos el concurso. Lima no vivió el grueso del conflicto, por lo que el centro debería tener otro tipo de misión más allá del memorial: la de coordinar las asociaciones de víctimas que se han organizado por medio de todo el territorio y han construido lugares de memoria sin ninguna ayuda del Estado. Es decir, que el edificio tenga un rol de coordinador de estas 
distintas asociaciones a lo largo del país. Por ello, este lugar va más allá de ser un sitio de celebración y conmemoración para convertirse en un espacio de resistencia ante la pérdida de memoria y la indiferencia.

Falconi/Infante: Regresando al tema del paisaje, habría dos aspectos que puntualizar. El primero es la utilización de un lenguaje arqueológico para poder compenetrarse con el paisaje desértico -esta pareciera que es una de las prácticas más plausibles y centrales que ustedes han desarrollado para echar mano a una suerte de vocabulario vernacular para poder compenetrarnos con el paisaje porque todos los peruanos vivimos al lado de una huaca y excavaciones. No es nada raro vivir al lado de una excavación arqueológica. Pareciera que ustedes han recuperado ese lenguaje muy conscientemente a modo de mediación con el paisaje, anteponiéndole la historia. Por otro lado, en tu libro, regresas casi 600 años para reconsiderar el paisaje peruano, lo que deja de lado a todo el periodo "occidental" (Conquista, Colonia y República). Sin embargo, ¿rescatas algo de este periodo?

Crousse: Estoy de acuerdo contigo en torno a la importancia de la historia; sin embargo, no es la única fuente para nosotros cuando hacemos proyectos. Lo que hacemos no es regresar 600 años atrás, sino continuar una tradición que empezó varios miles de años antes. Esta tradición no se interrumpió con la llegada de los europeos, aunque sí sufrió de un debilitamiento generalizado por una falta de voluntad (o de capacidad) de seguir construyendo el paisaje con el mismo entendimiento. Rescatamos de la Colonia, por ejemplo, la arquitectura de las casas hacienda y los ranchos de los balnearios en los que sí había una relación con el paisaje. Me refiero a los porches de los ranchos (el espacio de mediación entre interior y exterior) y los de las haciendas coloniales, construidas sobre plataformas, en donde se adoptan las mismas estrategias de las huacas prehispánicas (muchas haciendas fueron construidas sobre huacas). En los terrenos relativamente llanos de la costa, las huacas creaban una singularidad artificial que se relacionaba con las otras singularidades geográficas del lugar, creando, así, una red de espacios significantes y sacralizados. Lo mismo sucedió con los hacendados, quienes, para controlar el campo, construyeron sus casas en sitios elevados. Por tanto, no hay interrupción de esta tradición y esta continuidad, es una de las características subyacentes del paisaje peruano, que perdura hasta hoy, sobre todo en comunidades alejadas de las ciudades.

Esta tradición sigue viva en edificios como el de Mario Bianco en la Universidad Nacional de Ingeniería, en los proyectos de Santiago Agurto y en los miembros de la agrupación Espacio, que fue la primera de carácter multidisciplinario, con artistas, escultores, arquitectos, periodistas, etc., que trabajaban en conjunto. Si bien esta agrupación entendía los proyectos por medio de un lenguaje 
moderno y universalista, mi opinión es que se continuó con esta tradición. No encuentro una disrupción, sino más bien lenguajes muy distintos con una misma actitud hacia el entorno. Es posible que sea una tradición minoritaria y limitada a pocos ejemplos, pero es una tradición al fin y al cabo. No es una vuelta a la nostalgia -lo que más detesto es la nostalgia-, sino una continuidad que quizás se manifiesta en menor medida desde la llegada de los españoles y más ahora con la globalización. No se ha escrito o teorizado sobre ella, y yo no tengo todas las herramientas para hacerlo, pero sí tengo la convicción, desde el punto de vista proyectual, que cuando se hace arquitectura no se refiere únicamente al espacio construido, sino también al paisaje. Seamos claros, la arquitectura se ve modificada por el paisaje y no al revés, como se tiende a entender comúnmente. A mí me interesa rescatar esa tradición, no regresando a lo precolombino, sino refiriéndome a esa tradición en donde la arquitectura se transforma por el paisaje.

Falconi/Infante: ¿Qué proyecto tuyo, además del Lugar de la Memoria, puede ilustrar esta actitud?

Crousse: El edificio universitario de Piura toma el paisaje del bosque seco como su punto de partida, es decir, se basa en la capacidad de este bosque de producir sombra para poder habitar el territorio. Esto hizo que el programa del edificio no tenga ya un tipo arquitectónico predefinido (en este caso, el pabellón), sino que este pueda descomponerse en una ciudadela -que es un bosque de edificios que dan continuidad a la forma como se habita el lugar. Esto no lo hubiésemos podido hacer sin una relación histórica, sin una apreciación de cómo los antiguos arquitectos en Perú resolvieron esos problemas, pero eso no significa caer en una mirada nostálgica de querer regresar hacia lo precolombino o pensar que todo tiempo pasado fue mejor. Hay que recordar que las culturas precolombinas también depredaron y desaparecieron por gestionar mal el territorio y lo que vemos nosotros hoy son las que sobrevivieron y fueron más exitosas. Desde esa perspectiva, entendemos el legado y la tradición, que tenemos que insertarnos en ese legado para resolver los problemas de hoy con una mirada crítica y sin nostalgias a la historia.

Falconi/Infante: ¿Cuándo crees que la preocupación por el paisaje se vaya a convertir en una categoría tan sólida como lo es la sustentabilidad?

Crousse: Yo creo que en Perú, como quizás en menor grado en otros países de Latinoamérica, siempre estamos haciendo catching up de lo que sucede afuera. Tal vez aquí puede sentirse más fuerte porque los años de conflicto son más recientes, e hicieron que la gente se retrotraiga al dominio privado. Y como el paisaje es necesariamente dominio de lo público, este ha quedado atrás. Recordemos que en Perú todo lo que está afuera ha sido 
sinónimo de peligro, casi como en el Medioevo. Esto ha retrasado la idea de paisaje como algo que tiene que ser tomado en cuenta por todos los proyectos de ciudad. El problema no es si va a llegar o no, sino cómo va a llegar. Por ejemplo, en el caso de la sustentabilidad, esta ha llegado como un branding, como certificación LEED, etc., que nada tiene que ver con el sentido común de entender la economía de medios de cualquier proyecto como un valor que hace que cualquier edificio sea sustentable. Así, la sustentabilidad no es una consciencia real y se ha reducido a una mera lista que hay que completar sin pensar en condiciones locales. Por ejemplo, muchas de las normas de las certificaciones de sostenibilidad están hechas por la industria del mundo industrializado, que no tienen relación con lo que pasa por aquí.

Si esto lo llevas al plano del paisaje, verás que a veces es hasta contradictorio cómo se opera. Por ejemplo, no es paisajísticamente "correcto" introducir árboles que vienen de Hawaii porque estamos al lado del mar y estos son más resilientes a la salinidad, pero si tú dices que tu proyecto de paisaje no contiene vegetación arbórea (porque en realidad nunca hubo árboles al lado del mar en el desierto costeño de Perú), a lo mejor te caen críticas por no "paisajizar" el entorno. Por ello, es muy importante discernir en nuestros países acerca de la relación que tenemos con el paisaje desde la profesión para que podamos crear consciencia de esto antes de que se convierta en una regla sin sentido. En nuestra ciudad, es más difícil aún el desafío, ya que no empezamos de un paisaje naturalmente "verde", sino construido totalmente para hacerlo fértil, en medio del desierto. Desde el momento en que se entienda el desierto como paisaje y no como vacío, la gente dejará de botar basura y desmonte. Esto podemos considerarlo como un inconveniente o podemos verlo como una enorme oportunidad -pues es uno de los pocos desiertos que realmente se pueden habitar muy fácilmente, por la humedad, por la nube que tenemos encima, las temperaturas moderadas, la presencia de torrentes de agua, etc. Ahí está el reto de la consciencia del paisaje en la arquitectura y en la gente, en general.

Falconi/Infante: ¿Cómo apoyar la creación de esa consciencia? ¿Vía la pedagogía?

Crousse: Lo que estamos haciendo en la maestría es justamente tratar de borrar la distinción entre arquitectura, paisaje y territorio. Al tomar todo como un constructo proyectual, se caen ciertos tabúes con respecto a la posición que se debe tomar frente al paisaje (conservación, preservación, etc.). Y en un país con una diversidad ecológica como la de Perú, en que se tiene desde desierto hasta Amazonía, a lo que queremos llegar es a generar lógicas proyectuales para operar sobre ellos en conjunto. Queremos construir el paisaje como se ha hecho siempre a través de la historia. Esto no significa 
que no construir es un imperativo para mantener nuestro paisaje, sino que este debe ser construido con sus propias lógicas y, para ello, es necesario, como ya dijimos, reengancharnos con nuestras propias tradiciones, con la historia de la gente que ya modificó ese paisaje. La historia es una decantación de casos exitosos, que no son más que las huellas o las capas que sobreviven en el tiempo.

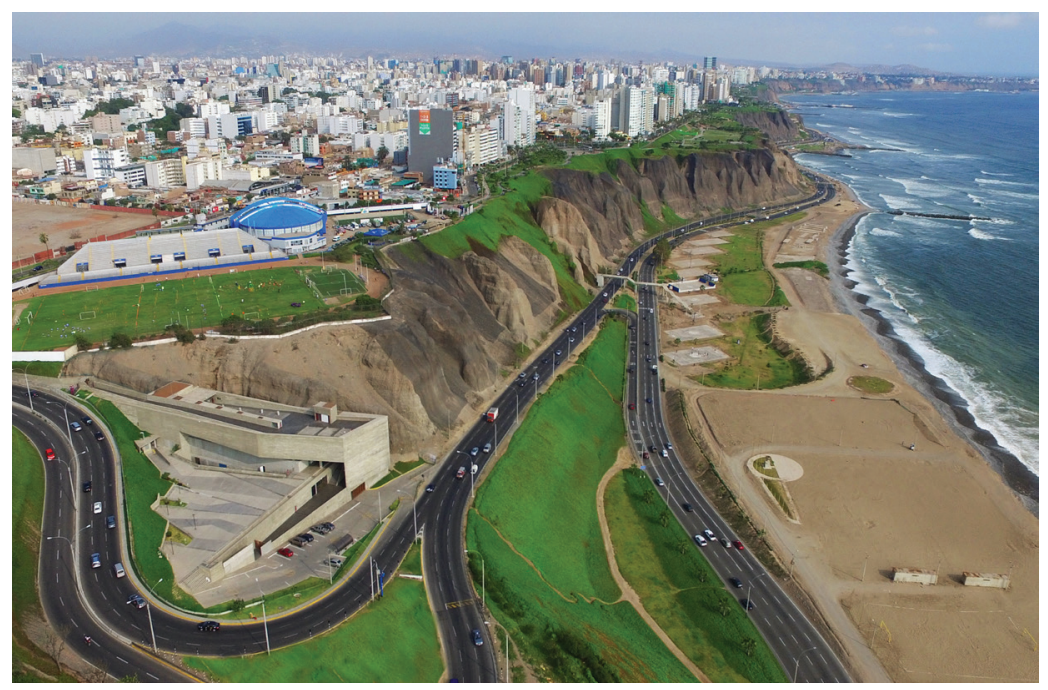

Figura 4. Lugar de la Memoria (2013) (C. Alfonso Casabonne.

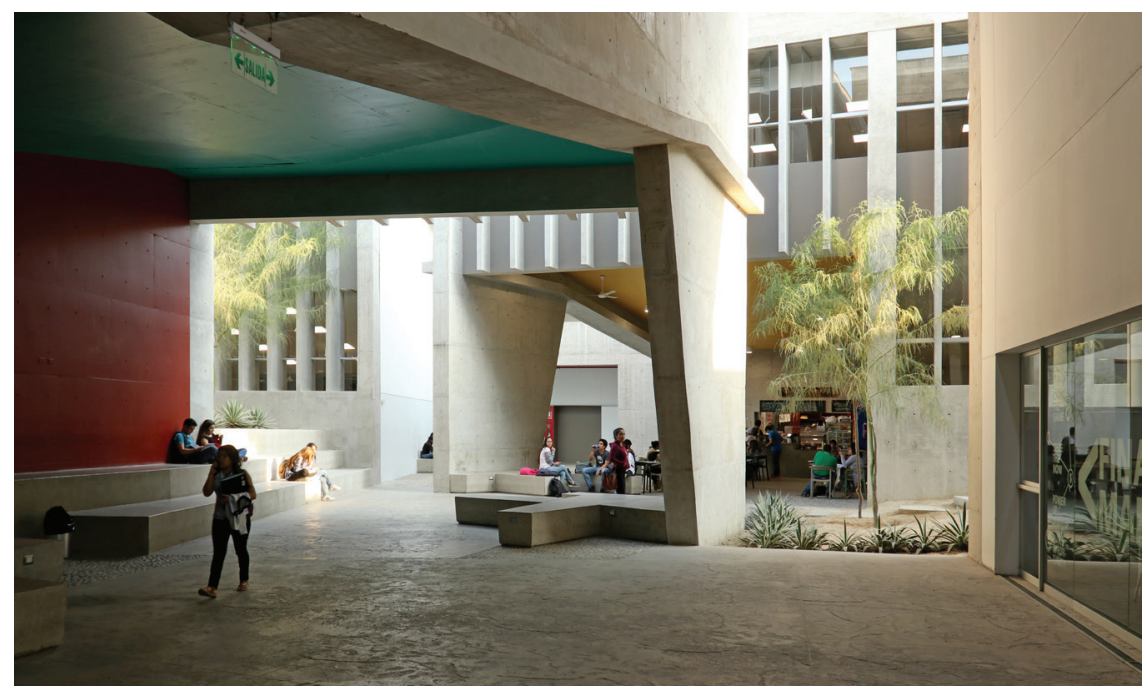

Figura 5. Universidad de Piura (2016) (c. Jean Pierre Crousse. 


\section{ENTREVISTA LLONAZAMORA: Michelle Llona}

\section{y Rafael Zamora}

\section{Liima, Perú}

Falconi/Infante: Al evaluar su práctica profesional en los últimos años, ¿cómo ven el paisaje en relación con la arquitectura peruana en la actualidad?

Llonazamora: En la arquitectura peruana actual el tema del paisaje es muy secundario. El término empieza a aparecer por todos lados luego de que las últimas obras más destacadas de la arquitectura peruana de relevancia internacional son en su mayoría obras que no están entre medianeros ${ }^{22}$. Entonces, son obras que están expuestas o a contextos arqueológicos o a contextos naturales extremos. De este modo, la temática existe, pero, en realidad, no hay proyectos de arquitectura del paisaje como tal. Hay mucho interés por parte de estudiantes en el tema, pero diríamos que es muy difícil hablar de referentes nacionales.

Falconi/Infante: ¿A qué creen que se deba eso?

Llonazamora: Les respondemos con una anécdota. Hace unos 8 años, un arquitecto peruano, sumamente culto, regresaba de EE.UU. de una exposición de Frank Lloyd Wright, y comentó que estaba muy sorprendido de ver que los planos de Wright estaban llenos de "bolitas", y que en realidad se trataba de la simbología de todas las plantas asociadas al proyecto, incluso con los nombres para identificarlas.

Nosotros creemos que hay una ausencia histórica dentro del espectro al que se dedican los arquitectos con el tema del paisaje y más bien se ha manejado de manera intuitiva, con el paso de los años, pero no se ha logrado dentro de la disciplina estabecer cierta teoría o una manera de hacer frente a este tema $y$, finalmente, quienes lo trabajan son especialistas de otras disciplinas, como botánicos, biólogos, agrónomos, ecólogos, entre otros, con un enfoque más cercano a la jardinería que a la arquitectura del paisaje.

Hace poco vimos un manual chileno en Archdaily Perú que promovía las especies nativas para el arbolado en espacios públicos ${ }^{23}$. Sin embargo,

22 Se refiere a los edificios recientemente premiados en Lima, como el Edificio UTEC de Grafton Arquitectes, ganador de la primera edición del Premio Internacional RIBA en 2016; el Museo de la Memoria de Barclay \& Crousse, ganador del premio Oscar Niemeyer para la Arquitectura Latinoamericana en 2016; el Museo de Pachacamac de Llosa-Cortegana, finalista del Mies Crown Hall Americas Prize (MCHAP) 2016; entre otros.

23 Minvu y Gehl Architects presentan esta guía descargable sobre el análisis y diseño del espacio público (3 de noviembre de 2017). www.archdaily.com. Recuperado de https://www.archdaily.pe/ pe/882597/minvu-y-gehl-architects-presentan-esta-guia-descargable-sobre-analisis-y-diseno-deespacio-publico 
cuando te das cuenta de que Lima es un desierto y las especies nativas son sumamente reducidas, queda claro que esta receta no es lógica, es una idea absurda. Sin embargo, lo interesante es que hay un ideario cultural flotando en el aire en las generaciones nuevas que tienen ya incorporado el concepto de ecosistema, de proyectos más conscientes.

Creo que ahora no podemos ver buenos o grandes ejemplos de proyectos de paisaje en Perú porque todavía estos temas se entienden como algo decorativo. A nivel urbano, el paisajismo es meramente decorativo, y a nivel regional, esto que podría ser una cosa muy potente, no existe.

Creemos que Perú tiene un legado muy importante en paisajismo si consideras la contundente herencia de las culturas que se desarrollaron en este territorio por miles de años. Esta herencia patrimonial puede enlazarse a temáticas como la de "paisajes culturales", pero fundamentalmente representa la expresión de un enfoque local y específico de intervención paisajística. Es posible señalar la importancia de los estudios que se vienen realizando a nivel académico, poniendo en valor y contexto actual todo este legado, es el caso de los textos de José Canziani, que, sin duda, serán complementados por nuevos estudios a futuro ${ }^{24}$.

La ventaja radica en que se trata de un territorio que requiere de la intervención paisajística para volverse habitable y sustentable, es decir, que la tecnología, la artificialidad y las lógicas antrópicas de la intervención son componentes ineludibles. Estas condiciones son propicias para la intervención y el proyecto de paisaje, son la justificación de su existencia, por esto Perú debe volver a ser un territorio a la vanguardia de la producción de proyectos de arquitectura del paisaje.

Falconi/Infante: La arquitectura, como cualquier otra disciplina tiende, por un lado, hacia las corrientes internacionales que buscan modernizarse y estar a la par con el mundo; y, por el otro, a transformarse en escuelas locales. Pareciera que estamos llegando al convencimiento de que el paisaje es una categoría tan significativa para la arquitectura que no puede desligarse de su práctica. Espero que de alguna manera llegue a ser considerada como la sostenibilidad, un concepto que antes era marginal, pero que ahora es absolutamente central dentro de la arquitectura. De alguna manera, el paisaje pasa a ser como una segunda versión de esta sostenibilidad asociada a un proceso ecológico y a un trabajo en torno a la naturaleza. Es decir, la sostenibilidad se convertiría en el primer estadio de esta supercategoría

24 José Canziani es doctor en Arquitectura y Urbanismo. Su quehacer está principalmente ligado a la investigación de la historia del urbanismo, la arquitectura prehispánica, el manejo del territorio y los paisajes culturales. Ha publicado un conjunto de artículos, entre los que destaca su libro Ciudad y territorio en los Andes (2007). 
que podríamos llamar paisaje, que tiene que ver con el contexto humano, la historia y la naturaleza. ¿Eso es lo que están tratando de decir?

Llonazamora: Sí. Lo que sucede es que el concepto de sostenibilidad está más relacionado con las ciencias exactas, con la huella de carbono, la economía de recursos, etc., y a nuestro parecer, el paisaje pareciera mucho más vago y, por lo tanto, mucho más difícil de aprehender para la arquitectura.

Ahora bien, hay una historia de la arquitectura paisajista en Perú. Ernesto Gastelumendi, por ejemplo, el gran profesor de Paisajismo y Jardinería de la UNI, tuvo una práctica asociada al arbolado urbano fundamental para varias generaciones de arquitectos en este país ${ }^{25}$. También Rafael Cubas, profesor de la Universidad Ricardo Palma, hizo un manual que es importante referente para la práctica del paisaje y espacio público ${ }^{26}$. También hay una deuda desde la historiografía, falta registrar e investigar los aportes a la arquitectura del paisaje en Perú. Hay que señalar los nombres clave de cada época, delimitar las escuelas y los periodos de cambio, inflexión o madurez.

Hoy en Perú la arquitectura no solo tiene que ser sostenible, sino que tiene que ser rentable, y eso es bien difícil en términos de paisaje. La arquitectura tradicional tiende a ver el proyecto con una temporalidad muy limitada, algo así como "llave en mano", el proyecto de arquitectura como algo que se acaba en su construcción. Un proyecto de arquitectura del paisaje es, más bien, un proyecto de tiempo, donde los elementos quizás consigan su equilibrio óptimo con los años, ya que hay componentes que poseen otros ritmos, el agua, el viento, las plantas, la fauna, etc.

Hace algunos años un grupo de profesores de la Pontificia Universidad Católica del Perú fue a hacer su maestría a la Universidad Diego Portales de Chile justamente en temas de territorio y paisaje. Lo interesante es que una de las tesis que se hicieron en este contexto fue el material base para el libro El paisaje peruano, de Jean Pierre Crousse, este libro representa, de alguna manera, un punto clave para una discusión sobre esta temática en el mundo académico peruano (Crousse, 2016).

Falconi/Infante: ¿Qué otros referentes habría fuera de la academia?

Llonazamora: Creo que la alcaldía de Susana Villarán fue otro momento importante relacionado con estos temas de paisaje, espacio público y ciudad.

25 Ernesto Gastelumendi fue arquitecto y urbanista. Director del Instituto de Planeamiento entre 1966 y 1970 en el gobierno de Fernando Belaúnde, tuvo especial interés en el paisaje urbano, la densificación de la ciudad y la conservación del patrimonio. Para mayor información de su obra y escritos, ver: Colegio de Arquitectos del Perú (2010).

26 Se refiere al reciente libro Arquitectura Paisajista del arquitecto Rafael Cubas, disponible en el siguiente enlace: https://goo.gl/Gp1qsF 
trabajo que se hizo en Serpar fue muy interesante, en él se desarrollaron varios parques zonales que lamentablemente no se han terminado de ejecutar o que fueron modificados por la alcaldía de Castañeda ${ }^{27}$.

Falconi/Infante: Es interesante que ya exista preocupación por estos temas en el país. Sin embargo, pareciera que todavía no hay una versión local de proyectos en paisaje porque estamos frente a una mala traducción del imperativo. A esto se les ha llamado "ideas fuera de lugar", por las que dictums internacionales son traducidos de cualquier manera a una realidad local sin importar sus especificidades y lo que termina sucediendo son malas versiones del mismo.

Llonazamora: El problema es más complejo. Por ejemplo, en 2011, la oficina Poggioni+Biondi, que tiene una gran preocupación por lo sostenible y el paisaje, hizo un proyecto en Lurín al cual nos invitaron a hacer el diseño de los jardines y exteriores ${ }^{28}$. En ese momento, diseñamos un jardín desértico y con alta resistencia a la sal como respuesta específica para un terreno costero en Lurín. Lo sorprendente es que después de un año y medio de construido el proyecto, nos dimos cuenta de que habían desplantado todo y lo habían reemplazado por césped. Es decir, el primer proyecto de paisajismo industrial desértico en Perú logró avanzar hasta su ejecución y realización, pero no pudo sobrevivir a los prejuicios y el mal manejo del mandante.

El sistema inherente al encargo de arquitectura involucra a un mandante, quien no tiene ninguna necesidad de estar "al día" con los postulados o avances a nivel académico. Entonces, el arquitecto asume un trabajo doble, como proyectista y consejero o pedagogo de un cierto "espíritu de la época". Este encargo extra debiera contar con otros sistemas de apoyo, revistas, televisión, etc. No vamos a poder educar a los mandantes de a poquitos, proyecto por proyecto.

En el caso de Perú, es importante destacar que la intervención de arquitectura del paisaje forma parte fundamental de los sistemas precolombinos de habitabilidad y desarrollo territorial. El ideal sería que así como la imagen de Perú ha llegado a asociarse con la riqueza y calidad de su comida, también

27 El Servicio de Parques de Lima (Serpar) es la organización pública que administra los parques metropolitanos de la capital de Perú. En el periodo de Susana Villarán como alcaldesa de Lima (2011-2014), se plantearon una serie de propuestas de parques para Lima que relacionaban el espacio público con la condición ecológica y biodiversidad de Lima, compiladas en el libro Lomas de Lima: futuros parques de la ciudad (Serpar, 2014). Estas propuestas no se llegaron a concretar en la siguiente administración del alcalde Luis Castañeda Lossio, actualmente en curso.

28 Poggione+Biondi es un estudio de arquitectura, en Lima, dirigido por René Poggione y Susel Biondi, que busca crear proyectos bellos, eficientes en lo ecológico y económico, y la sostenibilidad ambiental, social y cultural. Para mayor información, ver www.poggionebiondi.com 
debería estar asociada a las grandes obras que reconfiguran el territorio para hacerlo habitable.

Falconi/Infante: Entonces, ¿podríamos postular que una forma de ayudar a una traducción correcta sería ayudándonos con la historia precolombina? De alguna manera, regresar a la historia precolombina le permite al peruano encontrar una voz paisajística propia. ¿Es esta una posibilidad?

Llonazamora: Sí. Sin duda, el manejo ancestral de los valles del Pacífico en los Andes Centrales es una de las obras paisajísticas más importantes de la historia del continente, y no ha podido ser superada por ninguna obra de la era posconquista, o de la época Republicana, ni la actual. El potencial redescubrimiento de esta infraestructura paisajística, como manejo integrado en temas de riego, canales y santuarios y asentamientos, pone en evidencia el nivel de artificialidad de la naturaleza: un territorio labrado con sabiduría y técnicas locales, lleno de inventiva y belleza en su simple genialidad. Si recuperáramos este legado, en los sistemas y escala de intervención, estaríamos ante una nueva práctica del paisaje en este país.

Esta vanguardia de la que estamos hablando se da únicamente a nivel teórico, pero, en la práctica actual, nadie lo hace. Existen proyectos que son referente a nivel teórico, pero no se ejecutan porque no existe voluntad política ni interés de la cultura en estos temas.

En nuestra opinión, creemos que todo esto pasa por una condición debilitada en el ideario del Perú actual: el problema de "lo público". Cada país posee una cierta madurez en su concepción como comunidad, así es que en Perú hay mucho orgullo por los verdaderos tesoros de infraestructura pública y paisajística, como Cuzco o Machu Picchu, pero esto no se traduce en un sistema identitario de intervención. Es decir, nos asociamos a los monumentos, pero no creemos que cualquier intervención actual debe tener coherencia con ese nivel de calidad y genialidad. La construcción más importante de la arquitectura del paisaje no está en las obras, lo fundamental es la edificación de una identidad operativa cargada de valores que le permita a una sociedad avanzar y desarrollarse.

Lo que no nos gusta de la ciudad es reflejo de algo sin pulir o desarrollar en nuestro ideario como comunidad. El espacio público es central en los temas de paisaje porque es la construcción física, colectiva, que tenemos como comunidad, como ciudad, como país. Si tú ves postales antiguas, ves que Lima tenía mucho verde. Pero nadie se puso de acuerdo en cómo conservar esto, pues había que disponer de los recursos de todos para mantenerlo. En contraste, si miras el caso de Santiago y del cerro San Cristóbal, en el centro de la ciudad, ahí te das cuenta de que una comunidad entera se puso de acuerdo 
hace muchos años en regar un espacio que iba a ser usado por todos: porque era su espacio público. Mientras no exista esta noción de "lo de todos" -de lo público en Perú-, no van a existir prácticas de paisaje bien ejecutadas. Si creyéramos en lo público realmente a nivel institucional, tendríamos una costa verde increíble, un borde del Rimac decente, etc., pero como no existe interés, lo único que termina siendo rescatable a nivel de paisaje son las iniciativas ciudadanas. Los laureles plantados en Barranco, por ejemplo, no fueron iniciativa del Municipio, sino de la organización de los vecinos. Lo mismo con los jardines del tren eléctrico: iniciativas individuales de gente que hizo su chacrita en el terreno vacío mientras estuvo paralizada la obra.

Falconi/Infante: ¿Han visto el video del dron sobre Lima en Año Nuevo ${ }^{29}$ Creo que es una cosa impresionante y justamente se debe a la no centralización.

Llonazamora: Así es. El espectáculo que se produce es el resultado de la sumatoria de muchas personas que tiran fuegos artificiales, es lo que genera un Año Nuevo tan entretenido. Pero también habla de una ausencia de organización. Creo que hay una desconfianza generalizada entre todos los peruanos que hace que la sociedad no se sienta cohesionada. Pienso que de las cosas más valiosas que ha aportado Perú, en temas de paisaje y territorio, es lo que ha hecho el pueblo, la gente. En este sentido, la experiencia que tuvimos en Aguadulce, por ejemplo, fue alucinante y sumamente interesante en temas de espacio público ${ }^{30}$.

Falconi/Infante: Pareciera, entonces, que hay un problema social de fondo: la ausencia de alguien o de algo que pueda poner de acuerdo a todos para generar "lo colectivo".

Llonazamora: Sí. Creo que hay una falta de fe en la capacidad de organizarnos, en que si alguien está a cargo, nos está robando. Es decir, hay una situación generalizada de desconfianza que refleja un cierto estado de orfandad, de "no comunidad". Y esto incide en el pobre resultado de los proyectos paisajísticos. Si bien creemos que hay una nueva generación interesada en temas de paisaje, ciudad y territorio (quienes hicieron el PLAM para Lima o los que estuvieron trabajando en la alcaldía de Susana Villarán),

29 Se refiere al siguiente video: https://www.youtube.com/watch?v=Uc8e5Ke0bT8

30 Fue un curso electivo llamado Lecturas Urbanas, que Michelle Llona, Rafael Zamora y la artista peruana Sandra Nakamura realizaron en la Facultad de Arquitectura en la Pontificia Universidad Católica del Perú, referente a espacios urbanos de la ciudad de Lima que les parecía de interés. Se concentraron en cuatro sitios: la playa de Aguadulce, La Maná, el tren eléctrico (antes de su reactivación) y el centro comercial informal Polvos Azules, en el centro de la ciudad. El objetivo era registrar estos espacios para tener una lectura de Lima mediante fragmentos intensos y desde el punto de vista que el alumno quisiera, lo que fue sacando a la luz las lógicas de ocupación y funcionamiento de estos sitios. 
son pocos los planes que llegan a concretarse ${ }^{31}$. Cambian las alcaldías y todo se regresa a cero, se reorientan los proyectos alineados a la administración de turno y no hay continuidad. Así, se pierden oportunidades. El proceso debe comenzar en una recuperación histórica para poder saber qué es lo que hay y también avanzar en un entendimiento crítico de la geografía peruana para poder entender el territorio en su totalidad. Con una geografía de Perú, que incluye fenómenos como El Niño, nada se va a resolver desde una perspectiva únicamente ingenieril.

Falconi/Infante: Ustedes, como equipo binacional, ¿ven mucho contraste con la tradición paisajística en Chile?

Llonazamora: Vemos una actitud distinta desde el inicio de la época republicana en Chile y que tuvo que ver con la idea de construcción de un país agrícola desde un inicio. Esa conciencia de lo artificial tiene arraigado un esfuerzo por regar, por plantar y por producir, que finalmente dan fruto en un territorio y sociedades como la chilena. Es el caso del aporte de Claudio Gay y su influencia en la construcción de una visión de país y territorio, que terminó ilustrando a la clase dirigencial. Estos mandantes inspirados en una visión concreta son los que hacen las obras de paisaje y territorio posibles. Por otra parte, creo que el hecho de que hayan existido bastantes precursores extranjeros en temas asociados al territorio y producción hizo de Chile un país que incorporó ideas e innovación muy rápidamente. Así, por ejemplo, tenemos el caso de Óscar Prager, quien diseñó y construyó el primer parque de flora nativa en la historia del país en la década de 1930, el cual generó una revolución en su tiempo ${ }^{32}$.

En Perú, en cambio, muchos de los esfuerzos se han olvidado porque están justamente en el espacio colectivo, y terminan siempre perdiéndose porque alguien los tiene que cuidar, regar, etc., y es precisamente esto lo que no ocurre. Quizás un historiador podría establecer que los espacios públicos en Perú se perdieron como consecuencia de la época del terrorismo, vivida a fines de siglo, pero si se contrasta con la situación vivida en Chile durante la dictadura, el resultado no es el mismo: en Chile, igual se siguió plantando y regando aunque con una marcada orientación "correctiva", en pro de un cierto civismo ilustrado, europeizado. Este sesgo es el que ha sido cuestionado por el paisajismo posdictadura, no sé con cuanta lucidez, desde sus perspectivas políticas.

31 El Plan Metropolitano de Desarrollo Urbano de Lima y Callao (PLAM) es un plan creado en 2014 para la planificación y el desarrollo de Lima Metropolitana a 2035. Para mayor información, ver plam2035. gob.pe/

32 Óscar Prager (1876-1970) fue un paisajista alemán que desarrolló gran parte de su carrera en Chile, donde residió largos años y en los que proyectó numerosos parques públicos y privados. 
Falconi/Infante: Quizás uno de los problemas de "lo colectivo" en Perú es el hecho de que existen demasiados grupos disímiles y hay que hacer un contrato para cada uno de ellos. En Perú, tienes que lidiar con el contrato colonial, el prehispánico, el de los indígenas, el de los afroperuanos, el de los migrantes chinos, el de los japoneses. En fin, un sinfín de visiones que tienen tantas capas y sustratos históricos que hacen muy difícil hacer tabula rasa, que se parece más al caso chileno.

Es interesante, por ejemplo, contrastar el siglo XIX en Latinoamérica. Chile y Argentina fueron los únicos que tuvieron periodos exitosos. Chile gana la Guerra del Pacífico, está en auge su economía, educación, etc. En cambio, México o Perú pierden territorio y las élites son incapaces de poder lidiar con el patrimonio del país y articular todos los problemas que vienen desde la Conquista. De esta forma, pareciera que Chile es un país que desde sus inicios se ordena y se enfoca en la producción agrícola del Valle Central y la tierra es vista como "la" riqueza de las élites chilenas, que son, sobre todo, terratenientes.

Llonazamora: Lo que sucede es que Perú tuvo un proceso distinto a Chile desde la Conquista porque tenía una presencia de riquezas mucho más importante que Chile. Chile era una pobre Capitanía y Perú era Virreinato. Desde el inicio que los españoles se aprovecharon fuertemente de las riquezas en Perú. Y esta cultura del "huaqueo"33, de tomar o robar cosas patrimoniales o sagradas solo por el valor del material, derivó en que, incluso, se hayan fundido cosas tan bellas que ya no tenemos registro.

Y esto puede extrapolarse a la depredación del territorio peruano en general. Lo triste es que lo que no se entendió es que la mayor riqueza del país es justamente que estaba lleno de intervenciones, lleno de ciencia y cultura para poder entenderlo.

Hoy estamos, por ejemplo, haciendo una fábrica para un packing de uvas, y nos hemos puesto a buscar referentes actuales de infraestructura industrial en Perú con una propuesta de valor, y casi no existen. Entonces, justamente esto refuerza mi punto: el potencial de la agricultura es enorme en este país, pero si no nos hacemos cargo colectivamente de esta situación, va a seguir siendo solo "huaqueo", lo cual es fatal no solo para la arquitectura, sino para el país.

Santiago se regaló parques desde un inicio. No se regaló un busto dorado conmemorativo. Los países deben regalarse valles, playas, bosques. Cosas que tienen nombre en la geografía.

Falconi/Infante: ¿Y qué ven hacia el futuro, entonces? 
Llonazamora: Yo creo que hay un tema fundamental que tratar en Perú para que los proyectos puedan efectivamente ejecutarse. Los historiadores y arqueólogos de este país son muy importantes, tanto así que creemos que el único país del mundo donde actualmente vale la pena estudiar arqueología es este. El problema es que hoy en el mundo de la arquitectura se ve a la arqueología como contraparte enemiga y esto no puede seguir pasando.

Falconi/Infante: Claro. Jaime Castillo nos comentaba alguna vez lo difícil que es hacer ciudad, desde cosas tan básicas como poner agua potable en lugares cercanos a sitios arqueológicos por esta visión casi sagrada de que el pasado no puede ser tocado de ninguna forma. $Y$ ahí aparece la pregunta de por qué el pasado es preeminente al futuro, por qué tiene que ser más importante que el futuro, ¿no?

Llonazamora: Exacto. Se tiene que construir presente para poder formar parte del futuro, porque, si no, seguiremos en la misma situación en que tenemos las huacas en esta ciudad: unos sitios olvidados y borrados ${ }^{34}$.

Nosotros llevamos bastantes años desarrollando proyectos de paisaje muy cuidados: el Parque Ecológico de Machu Picchu, intervenciones para poner en valor sectores de andenería inca, un parque cultural, entre otros. Podríamos hacer una publicación de proyectos de paisaje peruanos hermosos, pero no se va a construir ninguno porque no existe la voluntad política para enfrentar los conflictos sociales derivados de estos proyectos. Desde el mundo de la política, no hay fe en que el proyecto de Arquitectura del Paisaje genere réditos en el bienestar de la gente y, a la larga, en el propio proceso político. Por poner un ejemplo, la intervención de la avenida Atlántica en Río de Janeiro, en la que participó Burle Marx hacia 1970, es un proyecto tremendo de intervención de infraestructura y paisaje que terminó por sellar no solo el estándar de lo público para Brasil, sino que estableció una relación indivisible entre el contexto natural y la ciudad.

Esta intervención termina por desplazar la centralidad urbana hacia la costa y construir un ideario nacional e internacional, donde la atmósfera de la playa es el corazón del espíritu carioca, y por traspaso el del país completo. No importa cuánto genio y dinero se puso en Brasilia, la imagen de Brasil sigue estando asociada al mar, a la costa, a la playa y a esa playa en particular. Más fino aún: a ese patrón de pavimento.

Esta es la verdadera potencia del proyecto de arquitectura del paisaje: que en su expresión óptima, es capaz de reforzar o, incluso, modificar el ideario

34 Las "huacas" (vocablo quechua w'aka) son los sitios sagrados de las culturas andinas prehispánicas y que hoy forman parte de la trama urbana de las ciudades peruanas. Solo en la ciudad de Lima existen 54 huacas dentro de la ciudad. 
de una comunidad. Mejor aún para Perú, es capaz de construir la idea de una sociedad. Desde nuestros escritorios podemos seguir investigando y proponiendo especies nativas y hablar de ecosistemas e infraestructuras, pero si queremos que los proyectos se construyan, entonces tenemos que armar una comunidad de profesionales primero. Justamente, hay que generar un pacto entre distintos profesionales desde una lógica proyectual a futuro. Solo en la medida en que arquitectos, arqueólogos, historiadores, diseñadores e ingenieros puedan trabajar en una misma mesa para sacar adelante un proyecto de ciudad o de territorio, es que este paisaje peruano del presente va a poder ser construido con sentido y proyección. 


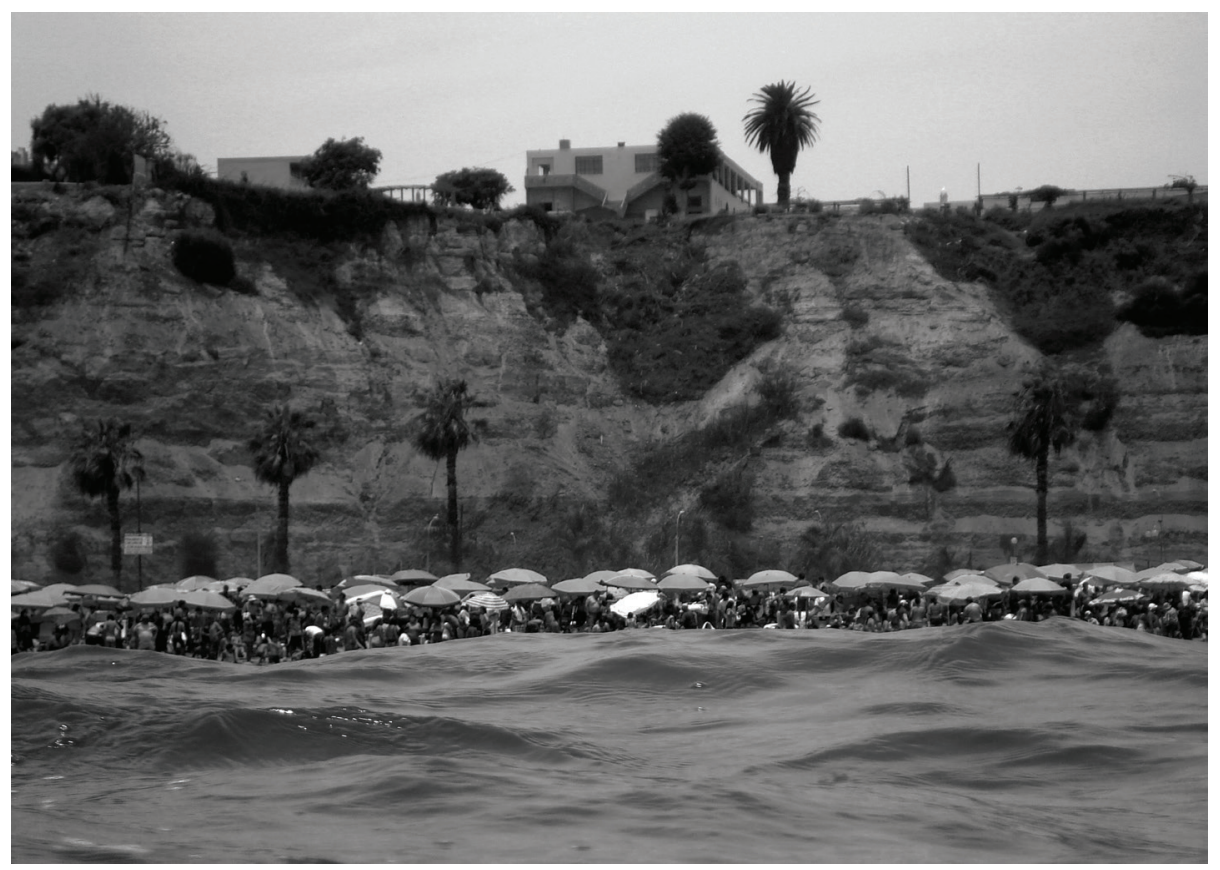

Figura 6. "Mar adentro / 12:30", proyecto de lectura urbana Agua Dulce (C. Claudio Solari.

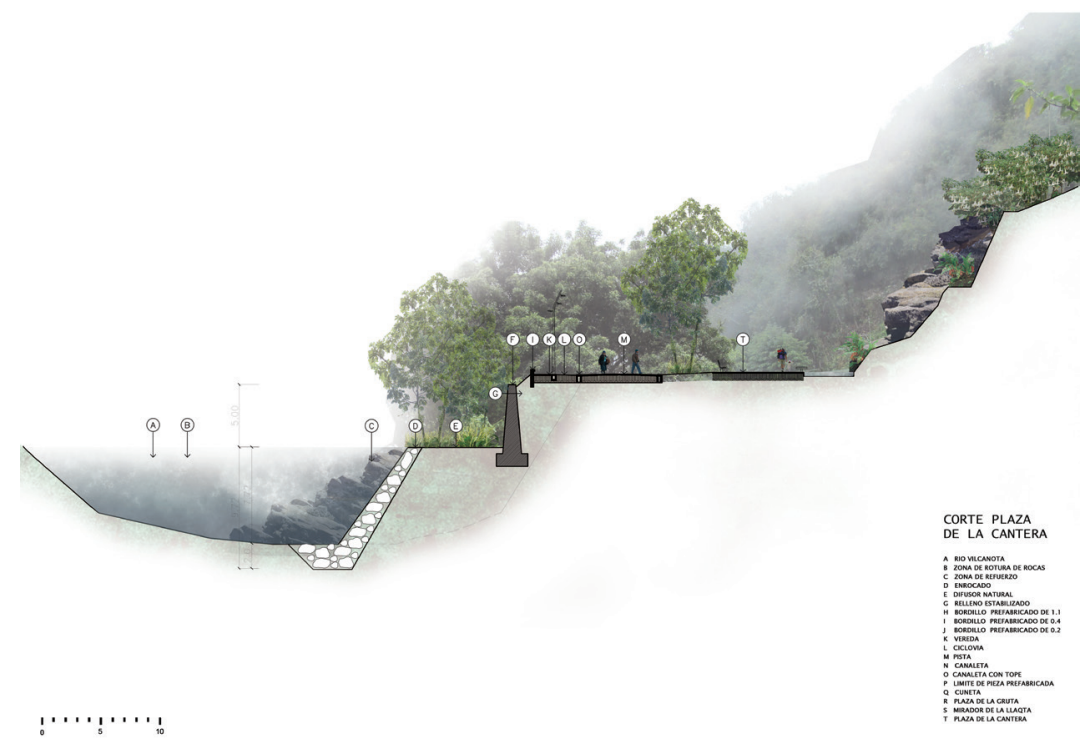

Figura 7. Proyecto Machu Picchu, alameda @. LLONAZAMORA. 


\section{ENTREVISTA PEDRO APARICIO Y FELIPE GUERRA}

\section{Bogotá, Colombia}

Falconi/Infante: ¿Cómo ven el paisaje dentro de la tradición arquitectónica colombiana?

Aparicio/Guerra: Lógicamente esta pregunta tiene una connotación muy particular en el contexto colombiano porque siempre ha existido en nuestro país una presencia pictórica muy fuerte que constituyó una escuela de paisaje y todo un imaginario construido por medio de este. Esta escuela de finales del XIX y principios del siglo XX se comienza a traslapar con las diversas olas de violencias y el paisaje, a asociarse con la colonización del monte o de los terrenos baldíos ${ }^{35}$. Esta puede ser una de las razones por las que se distanció el paisaje del diseño por muchos años en Colombia. Es más, creo que se llegó a formar una suerte de criminalización del paisaje -si es que entendemos al paisaje como un espacio fuera de la ciudad que termina siendo impenetrable por el conflicto.

Falconi/Infante: Es interesante porque el mismo giro verbal que utilizamos para la acción revolucionaria ("irse al monte") da cuenta de una conexión primigenia con la naturaleza. En el fondo, pareciera que rehacer un país en términos revolucionarios implicaba ir al monte y regresar de allí, ¿no?

Aparicio/Guerra: Sí. Las historias de todas las revoluciones a lo largo de América han estado siempre muy ligadas al paisaje, ya sea en el contexto colombiano, cubano, peruano, incluso en el norteamericano. Ahora, cuando conversamos de paisaje en el contexto colombiano desde la noción disciplinar, pareciera que Colombia ha tenido una escuela más ligada al urbanismo que al paisaje propiamente tal. $Y$ esta herencia se debe probablemente a la importancia e influencia de José Luis Sert, quien llega a Colombia entre 1948 y 1953 con el Town Planning Associates (TPA), y desarrolla planes para Tumaco, Cali, Medellín y Bogotá hasta asumir su posición como decano de la Escuela de Diseño de Harvard, como aliado para los proyectos de urbanismo que planeaban los Estados Unidos en la Guerra Fría para el continente americano (Castellanos, 2003).

35 Efectivamente, se considera 1893 como el año en que comienza el arte académico en Colombia con la llegada del pintor Luis de Llanos, quien luego enseñará en la Academia de Bellas Artes, y el regreso del pintor Andrés de Santamaría (ambos en 1893). Es gracias a la influencia de Llanos que apareció La Escuela de la Sabana (llamada así por ser la escuela desarrollada en La Sabana de Bogotá), la primera escuela paisajística del país y que luego extenderá su influencia. Por otro lado, si bien el "conflicto" colombiano actual data de 1964 -con la creación de las Fuerzas Armadas Revolucionarias de Colombia (FARC), luego de la represión de grupos sublevados en la región de Marquetalia-, Colombia ha sufrido a lo largo de sus casi 200 años de existencia continuas guerras internas, y que se inician en el siglo XX con la Guerra de los Mil Días (1899-1902). Para más información, ver Melo (2017). 
Ahora bien, es importante recordar que dentro de la práctica pictórica hay dos momentos importantes en la historia de Colombia. Por un lado, están todas las expediciones geográficas y botánicas que empiezan a exotizar el paisaje nacional e indagar su escala de manera pictórica, me refiero a Humboldt y a todos los demás exploradores etnobotánicos y extractivistas que llegaron a esta región, como también la deconstrucción del paisaje mismo en las láminas de herbario de la Real Expedición Botánica del Nuevo Reino de Granada. Y, por otra parte, la Escuela de La Sabana, que nace a finales del siglo XIX y desde donde se empieza a estetizar el paisaje y desde donde la hacienda, el terrateniente y la propiedad de la tierra son centrales como temáticas. Estos dos momentos marcaron muy profundamente la manera de entender el paisaje en Colombia y, ciertamente, han influido en cómo se entiende este desde el diseño.

Lo interesante de todo esto es que fue la cartografía de los expedicionarios la que generó este acercamiento al territorio, en cuanto supuso, de una forma tangible, tomarlo como propiedad e imponer un protocolo de asentamiento. Por ello, la Escuela de La Sabana está marcada por la noción de la productividad de la tierra, es decir, de mirar el paisaje como terreno productivo como única forma de dominar el paisaje.

Falconi/Infante: Sin duda. Es muy interesante que ustedes hayan notado cómo el paisaje recién aparece en términos pictóricos solamente cuando se puede tener una visión del territorio como productivo y ordenado en términos de propiedad privada. De alguna manera, este es el origen mismo de la tradición paisajística en general. De alguna manera, para que exista paisaje, tiene que haber una diferencia crítica entre sujeto y naturaleza. Colombia no se organiza de esta manera sino hasta muy tardíamente, y más bien lo que siempre queda es una versión exotizante y complicada del territorio, por lo que el paisaje nunca es un horizonte real en términos serios para el diseño, sino que solo es un elemento compositivo más. En este sentido, ¿qué proyectos últimos visibilizan al paisaje solo como elemento compositivo?

Aparicio/Guerra: Podríamos hablar de dos proyectos o concursos, más específicamente, que son el del río de Medellín y el del Museo de la Memoria. En estos dos casos, predomina el objeto arquitectónico y el paisaje se vuelve meramente compositivo, al punto de caer en una exotización. Es precisamente esa exotización la que nos hace reflexionar acerca de cómo sigue estando Colombia en la actualidad.

Falconi/Infante: ¿Ninguna de estas propuestas asume el paisaje como un instrumento real de análisis? 
Aparicio/Guerra: Exacto. Incluso en las propuestas de estos ejemplos, se plantea una manera de representar el paisaje de manera casi perversa en términos de "verde". Lo que hay es un exceso de verde que no está conectado con las condiciones propias de los lugares donde se insertan. Las imágenes de las propuestas muestran, por ejemplo, un Museo de la Memoria en medio de una especie de selva húmeda que no es viable a la altura sobre el nivel del mar donde se encuentra Bogotá. Y, en términos prácticos, el proyecto plantea una serie de conexiones naturales que no podrían ocurrir ecológicamente de este modo. Hay, pues, una suerte de abuso por parte de las herramientas de representación en los concursos, donde todos los corredores tienen árboles, los andenes también, y, de pronto, los proyectos son capaces de conectarse con todo lo que existe en Bogotá, lo cual es falso. Sin decir también que hay una falta de entendimiento botánico, en cuestión de escala y siembra, de la fauna que se presenta.

Que hayan llegado a ser propuestas finalistas en cada uno de los concursos nos plantea la pregunta de si es que hay una falta de conocimiento por parte de los jurados o es simplemente un método de persuasión técnica para componer una imagen en Photoshop, Illustrator o el programa que sea.

Falconi/Infante: $Y$ a esto podríamos agregar que estas imágenes siempre contienen indígenas y afrocolombianos como un elemento persuasivo perverso. Pareciera que lo que se busca es convencer a los jurados de que hay un nuevo paisaje que implica un nuevo contrato social y que es sobre todo armónico en todas sus partes.

Aparicio/Guerra: Lo que pasa es que también hay que mostrar la multiplicidad de capas y grupos sociales que tiene este país, pero lo que termina sucediendo en estas imágenes es que delatan la carencia del lente analítico del paisaje. Todas ellas están compuestas sin rigor: los árboles se pegan sin pensar en su tamaño y en el espacio que ocupan las raíces, los animales se presentan de una forma que no es real, etc. En el concurso del río Medellín ocurre algo similar: el esfuerzo por "tratar de volver al origen" solamente se ve a modo de ambientación en las orillas del río, no entendiendo realmente la complejidad de ese borde.

Falconi/Infante: Pareciera que solamente les interesa regresar a una imagen primigenia del río antes de que este haya sido canalizado, aunque solo sea por medio de la ornamentación, ¿no es cierto?

Aparicio/Guerra: Exacto. Por ello, es importante valorar proyectos como el de Luis Callejas y Camilo Restrepo, que plantean una reflexión más profunda y aterrizada acerca del paisaje, y que no reciben ninguna mención. Y lo que sucede es que hay una coyuntura interesante en la solicitación 
de un proyecto público de grandes piezas urbanas, pero falla una traducción entre la representación de un proyecto (la imagen concursera y ganadora, la cara política para la primera plana del periódico) y la complejidad técnica que tienen los proyectos, lo que termina colapsando el presupuesto a la hora de la ejecución de estos y se ve plasmado en la incapacidad de introducir el diseño a gran escala en la ciudad: en el proyecto del río Medellín, solo se logró consolidar una pequeña etapa. Y lo que termina sucediendo es que se construyen proyectos fragmentados o, peor aún, mutilados, que nunca se completan.

Falconi/Infante: ¿Y qué significaría estar "más aterrizados" en términos de paisaje?

Aparicio/Guerra: Pareciera que en Colombia el concepto de medio ambiente siempre está marcado por una tradición edénica.

Falconi/Infante: ¿Por qué importa tanto el retorno al Edén en Colombia?

Aparicio/Guerra: Es una muy buena pregunta, podríamos especular que la imagen del Edén siempre ha estado presente de manera muy cercana en Colombia. Basta con salir de la ciudad y nos encontramos con un monte que podría parecerse a la descripción del Paraíso.

Falconi/Infante: Sí. Pero, al mismo tiempo, uno sale de la ciudad al monte y termina muerto, ya sea por acción del hombre o de la naturaleza. Si no recordemos la enseñanza de La Vorágine, de José Eustasio Rivera, de 1924.

Aparicio/Guerra: Claro, pero La Vorágine se da en el Pacífico, donde hay condiciones absolutamente extremas y muy distintas a esta zona de Cundinamarca. Sin embargo, es interesante que las ciudades colombianas sí tienen la particularidad de encontrarse con bosques nativos a ellas. En Bogotá, por ejemplo, puedes irte en carro desde Quinta Camacho a un bosque nativo en 15 minutos. Esto da la sensación de tener constantemente un "retorno al Edén" casi morboso, si se quiere.

Falconi/Infante: Parece algo esquizofrénico. Es una suerte de "tengo mi finquita allá, tengo mi páramo allá y acá, en la ciudad, no tengo eso y no importa". ¿Es algo así?

Aparicio/Guerra: En Colombia, desde el colegio se enseña esta noción de que existe una inaccesibilidad al territorio, de que es imposible llegar a él; por tanto, ese territorio es siempre distante. Es posible que los proyectos a los cuales nos estamos refiriendo partan de esta idea.

Falconi/Infante: ¿Puede ser que, como el enfoque siempre ha estado puesto en el urbanismo, la ciudad colombiana ha pasado a ser un territorio 
sumamente denso y aglomerado, que sumado a los procesos de migración campo-ciudad por el conflicto han generado urbes caóticas sin infraestructura de espacio público o conexión paisajística, lo que engrandece el sentimiento de nostalgia, de necesitar ese "Edén de vuelta"?

Aparicio/Guerra: Pienso que es una hipótesis que valdría la pena revisar con más detalle. Sin embargo, lo que sí podemos decir es que cuando se comienza a hablar de la ciudad sostenible, ecológica, etc., en Colombia o desde la versión latinoamericana, lo que termina presentándose es una ambición de proyectos urbanos con interpretaciones de paisaje, pero sin las complejidades técnicas, teóricas ni filosóficas que este conlleva. Así, por ejemplo, el proyecto del río Medellín no entiende que es una infraestructura que debe considerar la creciente del río, la capacidad que pueden tener los bordes de absorber estas crecientes, ni tampoco su mantenimiento. Es decir, no entienden el medio ambiente. Y medio ambiente y urbanidad es lo mismo, debieran convivir al mismo nivel. Justamente, es este el que funciona como un filtro o medio entre la sociedad y la naturaleza, que, en el caso colombiano, la vemos como exuberante.

Falconi/Infante: Sin duda, el paisaje sería una forma de mediar. Quizás en Medellín, se ha podido dar de un modo distinto, pero en Bogotá, no. Es decir, la capital es una ciudad cerrada a la productividad hasta más o menos los años cincuenta. A las élites bogotanas nunca les interesó realmente el territorio más allá de Cundinamarca.

Aparicio/Guerra: Ocurre algo extraño en cómo nombramos, incluso, el paisaje. Por ejemplo, el hecho de que le llamemos "sabana" a La Sabana de Bogotá y que la entendamos como un gran plano productivo es confuso. En términos ecológicos, esto corresponde al altiplano cundiboyacense, es decir, un pie de monte de páramo, encharcado con humedales y niveles freáticos altos, con ecosistemas que drenan flujos de agua por gravedad por medio de cuencas fluviales y rondas pantanosas, hasta llegar a los meandros del río Bogotá. Esto es una meseta andina inundable con suelos difíciles para la construcción, pero ricos en nutrientes para la agricultura, y es muy distinto a lo que sucede en una sabana; por tanto, debiera pensarse de modo diferente. Debería llamarse de manera distinta.

Falconi/Infante: Es interesante el hecho de pensar en que a las élites colombianas, que fueron las que impulsaron la República, nunca les ha interesado la dominación geográfica del país. En cierto punto, es extraño. Las chilenas, por ejemplo, impulsan el dominio territorial, incluso por medio de guerras -como la del Pacífico- para dominar el espacio y explotarlo productivamente. Lo mismo sucede con las élites norteamericanas que llegan 
hasta California y eso que es un país diez veces más grande que Colombia. A los bogotanos jamás les interesó explotar el Chocó, por ejemplo. A 40 kilómetros tienes la zona esmeraldera, en la cual no puede entrar la ley, ¿por qué habrá esa falta de imaginación geográfica?

Aparicio/Guerra: En Colombia, existe un imaginario en el que siempre hay más territorio por descubrir y que no se puede dominar completamente porque es exuberante e interminable. $Y$, sin poder dar una respuesta a esa pregunta de manera disciplinar, sí es curiosa la idea de organización territorial como proyecto de diseño de los diversos países de América Latina. En Brasil, por ejemplo, está muy presente desde la arquitectura, con la escala de Brasilia o el mismo Paulo Méndes Da Rocha, que propone la organización de nuevas ciudades por medio de la intersección de corredores viales y fluviales. Acá hubo un momento específico en que la acción de las fronteras y la introducción de nuevas tecnologías trató de descentralizar Colombia, lo que produjo grupos regionales muy poderosos.

Falconi/Infante: ¿Puede ser que el hecho mismo de que las ciudades estén "ahogadas" en valles estrechos en Los Andes produzca un efecto psicológico-cultural de cierre, de "no horizonte", de sentir que no hay nada más allá "de lo que veo" y se generen estos sistemas cerrados ambiental y culturalmente? ¿Por ejemplo, la región antioqueña?

Aparicio/Guerra: Es cierto que siempre ha habido una condición de distancia portuaria, de información, del mundo en general. Bogotá siempre fue una ciudad que por su presencia geopolítica tenía control de los corredores que iban a Cartagena con el oro. Las decisiones de infraestructura fluvial y portuarias estaban fuera de Bogotá. La ciudad funcionaba porque había suficiente tierra fértil disponible, agua, minerales y madera, como también un confort térmico. Además, en el caso de Bogotá y de las ciudades grandes de Colombia, la condición geográfica hace que uno se demore mucho en transportarse justamente por la topografía.

Falconi/Infante: Claro. Esta es una condición compleja constante que atraviesan todos los países andinos.

Aparicio/Guerra: Pareciera que la pregunta que hay que hacerse, pensando en esta situación geográfica accidentada, con la posición centralizada de Bogotá en Los Andes, la dispersión de las metrópolis y otras élites y las diferentes porciones geográficas, es: ¿por qué la arquitectura ha estado tan alejada del proyecto de infraestructura y de conexión territorial?

Es muy posible que la escuela modernista haya entrado de manera muy fuerte con temáticas de ciudad únicamente. No es hasta ahora que en la Universidad de los Andes ha surgido un taller llamado "Territorio en Colombia" 
o una "Unidad de Paisaje", que comienza a abrir temas relacionados con el país. Es decir, recién se atisba una preocupación desde la academia bogotana por el imaginario nacional.

Falconi/Infante: ¿Y qué proyectos podrían resaltar como interesantes en este contexto? ¿Cuál podría acercarse a lo que hemos estado conversando?

Aparicio/Guerra: Creo que las unidades de planeación zonal urbanas que surgieron hace décadas son muy importantes como proyectos estatales. Hubo un concurso en el que ganamos como estudio, el cual promovía la reconstrucción de infraestructura educacional luego de las inundaciones producidas por el fenómeno de La Niña, en 2010. El concurso traía el imaginario de los colegios de manera muy tradicional y pedía infraestructura para las regiones Caribe, Pacífico, Andina y Amazonas, como si fueran unos globos terráqueos prístinos y homogéneos. Lo que nosotros propusimos fue que se podía escoger una, dos, tres o todas. Decidimos construir un proyecto prefabricado, en madera, accesible, que se puede mover para llegar a las zonas más vulnerables por medio de los ríos. Creo que había una reflexión muy profunda acerca de lo que significa desplazarse en las condiciones colombianas.

Falconi/Infante: Es decir, se dan cuenta de que la sociedad existe también, de que no es Colombia, naturaleza salvaje.

Aparicio/Guerra: $Y$ entender que el hacer ciudad ya es hacer naturaleza. Es decir, al canalizar un río, estás produciendo naturaleza nueva. Esto no quiere decir que no puedan existir elementos geométricos o estéticos dentro de los proyectos, pero sí es importante que el origen del proyecto arquitectónico nazca de la reflexión de la infraestructura, de la producción de lo urbano como un ente que produce naturaleza, que produce paisaje. Esto es lo que comparten los proyectos exitosos a los cuales nos referíamos. Que entienden que el paisaje tiene una performatividad que va más allá del hecho pictórico o de la forma en que fue representado. Por poner un ejemplo más específico: el hecho de plantear un corte técnico en un proyecto de estas características es estar pensando más allá, es estar entendiendo el suelo como el sustrato mismo junto a la raíz del árbol, comprendiendo las condiciones físicas, materiales y geofísicas en el tiempo, la permeabilidad del agua, el drenaje, los minerales, los químicos, la atmósfera y las partículas. Los proyectos de paisaje se diseñan no con espacio, sino con el tiempo. Como dice Pierre Bélanger: "paisaje es el diseño de flujos en el tiempo".

Falconi/Infante: Es decir, el espacio es una manera de concretar la temporalidad.

Aparicio/Guerra: Exacto. Mientras que la arquitectura, a pesar de que 300 tiene que funcionar en el tiempo, se ordena y diseña en términos de espacio, 
los proyectos de paisaje tienen una variable temporal que hace que el diseño mismo deba ser concebido desde el tiempo, desde el hecho mismo de que la naturaleza tiene vida propia y tenemos que trabajar con ella para crear lugares memorables, que logren hacer conversar la ciudad con el paisaje. El tiempo es un factor clave en conciliar estos dos mundos.

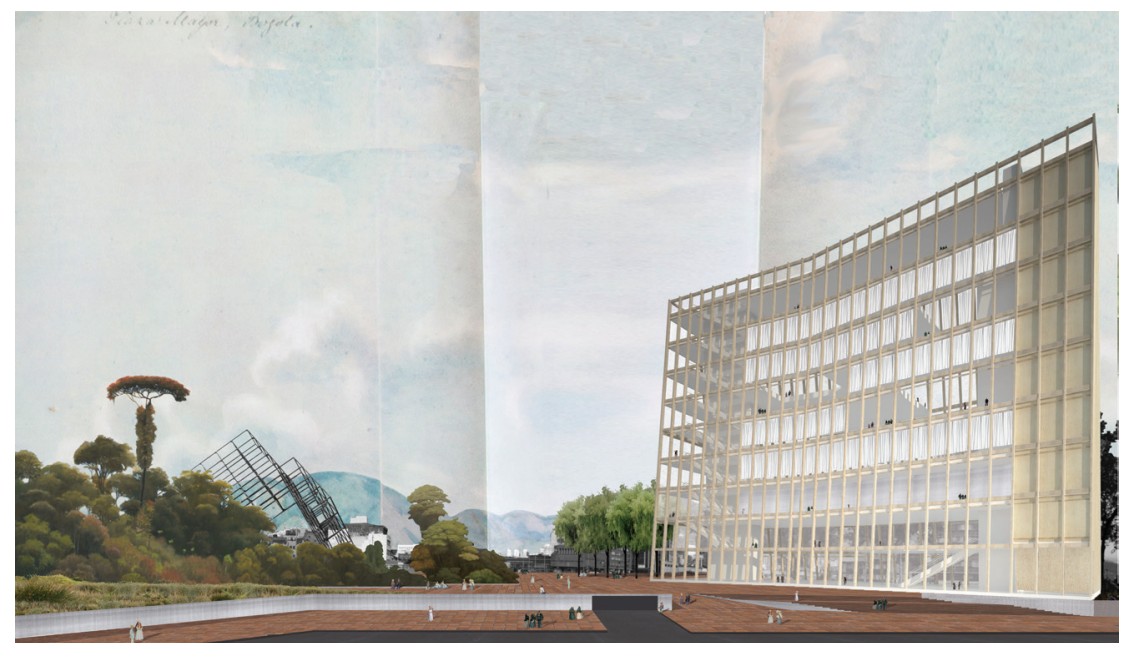

Figura 8. Perspectiva exterior del Museo de la Memoria, propuesta para el Concurso Nacional Museo Nacional de la Memoria (2015) @. Altiplano.

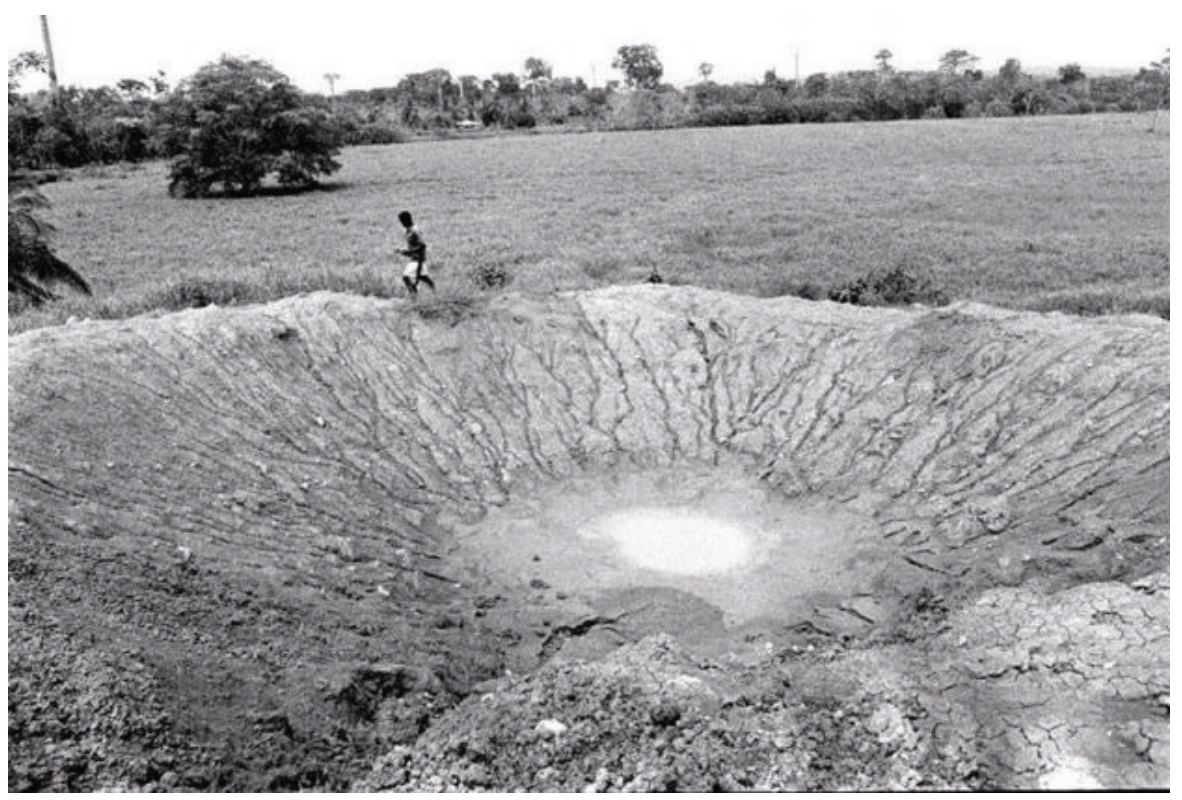

Figura 9. Sin título @ ○. Jesús Abad Colorado. 


\section{ENTREVISTA SANDRA ITURRIAGA}

Falconi/Infante: El desarrollo del paisaje en el escenario latinoamericano es muy lento y esto tiene que ver, en gran parte, con nuestra posición ante la modernidad. Así, por ejemplo, Latinoamérica no tuvo pintura paisajística por los 300 años que duró la Colonia, mientras que en Europa este era un género importante. Sin embargo, en las últimas décadas ha habido un interés importante en el paisaje, que ha tenido consecuencias tan interesantes como el proyecto Mapocho 42K que has venido desarrollando. ¿Qué nos podrías contar de esta experiencia? Y en relación con esto, ¿cómo ves tú la tradición paisajística en Chile? ¿Cómo ves tú esta relación con el paisaje y la tradición chilena?

Iturriaga: Santiago es una ciudad fundada en un valle semidesértico situado en una cuenca, que está atravesado por dos ríos, un territorio que se ha sabido aprovechar al máximo a través de su irrigación por canales artificiales y quebradas naturales. Los cursos de agua han dibujado un sentido de paisaje en la ciudad, pero creo que el reconocimiento de esta condición todavía es muy incipiente, mirado desde su tradición paisajística. De hecho, para ponerlo en contexto desde mi propia experiencia, cuando yo entré a estudiar Arquitectura en la Universidad Católica de Chile el año 84, estudiamos arquitectura "a secas", sin apellidos. Pero fue durante ese periodo que apareció uno de los primeros libros que puso la palabra "paisaje" dentro de la disciplina local. Me refiero a Santiago: espacio urbano y paisaje, escrito por Gross, Pérez de Arce y Viveros (1982). Este era el primer libro editado por autores chilenos, que hablaba de espacio urbano y paisaje como una ecuación a la par y que tenían, de alguna manera, el mismo peso específico. Para mí fue sumamente radical encontrarme con este libro: con planos y cartografías que tenían que ver con la lectura de sus aguas, que hablaba de la naturaleza del paisaje de Santiago, visto como uno de secano -y no verde como se sentía desde la ciudad-, la importancia de los canales, sus parques ganados al lecho del río, entre muchas otras cosas. Y es curioso, porque fue justamente con uno de ellos, Mario Pérez de Arce, con quien yo empecé el trabajo del río Mapocho, basándonos en una visión que él ya traía desde entonces. En este sentido, hay una línea venosa directa en mi concepción del paisaje en la ciudad, desde aquel libro hasta mi trabajo actual. Cuando me tocó trabajar directamente con él, Mario tenía 92 años, ¿se pueden imaginar el cúmulo de experiencias que tenía? Considerando que él nunca fue profesor mío, para mí fue vital compartirlas de manera directa, mediante conversaciones, de experiencias, visitando el río o hablando con los estudiantes. En este sentido, yo siempre digo que no se requieren solo títulos académicos para hablar con autoridad del paisaje. Al valor de esa enseñanza y experiencia directa yo le tengo un enorme agradecimiento. 
Falconi/Infante: ¿Y cuáles eran esas incipientes preocupaciones por el paisaje en los años 84? ¿Qué estaba buscando esta generación autodidacta, si podemos nombrarla de algún modo?

Iturriaga: Creo que lo que comento del libro es muy importante, porque tenía mucho que ver con recuperar el origen de nuestro paisaje, entender dónde están los elementos propios, cuáles eran sus componentes y sus huellas. Son cosas que podrían parecer de sentido común, me refiero a que conocimientos disciplinares en que hoy se habla de servicios ecosistémicos y ecología urbana estaban descritos en un lenguaje sensible, y que cualquier persona fuera de la disciplina podía entender. Con este libro, podías comprender que Santiago se asentó bajo unas condicionantes geográficas, climáticas, condiciones de suelo, condiciones topográficas, que la determinan al ciento por ciento. Y, en el fondo, estas condicionantes no pueden no importarle a un arquitecto con interés sobre el entorno, donde se construyen sus obras, y que en el caso de Santiago es comprender que está situada en un valle semidesértico, entre dos ríos, que tiene una pendiente muy específica producto de los rellenos aluvionales, y que está limitado entre la cordillera de Los Andes -que es una cordillera alta, joven y robusta- y la de la Costa -que es un cordón mucho más bajo y antiguo. Creo que esto es lo fundamental de esta generación autodidacta, con la que me formé: la transmisión de este amor por el paisaje, que venía de un conocimiento directo y que, en el caso de Mario Pérez de Arce según contaba, venía de la experiencia de subir los cerros y conectarse con el territorio que habitamos: mirar la cordillera, subir sus quebradas, encontrarse con la vegetación propia, que delimitan un espacio muy particular.

Falconi/Infante: Es muy interesante conceptualizar la visión de paisaje por medio de la experiencia, pero, cuando uno ve publicaciones actuales de arquitectura chilena, por ejemplo, a uno le viene a la cabeza una concepción de objetos bellos, puestos en sitios espléndidos y perfectamente delimitados. Es decir, hay una preocupación importante por este tema, pero, en este sentido, da la impresión de que hay una disociación entre objeto arquitectónico y el lugar donde se emplaza, no se entiende todavía como algo sistémico, sino solo de conexión estética.

Iturriaga: Yo te diría que es un proceso. Creo que esta noción de valorar "lo propio" en los proyectos de paisaje es algo que ha estado latente desde Óscar Prager, incluso desde antes. La visión de este paisajista austriacoalemán que diseñó el primer parque urbano con vegetación nativa como una gran ventana a la cordillera ${ }^{36}$ la podemos encontrar también más tarde

36 Óscar Prager (1876-1970) fue un paisajista alemán que desarrolló gran parte de su carrera en Chile, donde residió largos años y en los que proyectó numerosos parques públicos y privados. 
en la obra de Carlos Martner, especialmente en las piscinas del cerro San Cristóbal ${ }^{37}$. Martner y Prager potenciaron los elementos propios del paisaje natural de Santiago, reconocieron estos valores y también supieron qué plantas foráneas utilizar en este contexto semidesértico. $Y$ si bien aún uno puede ver proyectos donde el entorno está disociado del objeto arquitectónico, creo que existe en Chile cada vez más preocupación y valoración por nuestra vegetación endémica, por nuestras condiciones geográficas más propias y esto va permeando la cultura y los proyectos nuevos.

Falconi/Infante: Pareciera que en Santiago hay una noción más enraizada entre ciudad y naturaleza, que se vuelca en los proyectos que nos estás contando. Esto ya se puede ver desde inicios de la República, con la transformación del cerro Santa Lucía como el primer espacio público de la ciudad en que se asume lo problemático del terreno (lo rocoso, la pendiente, etc.) como una oportunidad de paisaje urbano ${ }^{38}$. Con esta misma lógica, se agregan luego el Parque Forestal, el cerro San Cristóbal y los parques de la ribera sur del Mapocho. ¿De dónde crees que viene esta predisposición para aceptar lo local como punto de partida?

Iturriaga: Yo diferenciaría, como parte de nuestra tradición local, el esfuerzo de domesticación del espacio privado -un espacio reducido como el jardín-, del espacio público -como fueron todas las obras de transformación de Santiago que se han nombrado y que le dieron una nueva cara a la ciudad, en los albores del Centenario de la República. Es interesante recalcar que Santiago hizo de sus hechos geográficos sus espacios públicos. Así, se integraron los cerros y el borderío al espacio de la ciudad: Ios cerros Santa Lucía y San Cristóbal, el Parque Forestal, el Parque Providencia, entre otros. Y creo que esta tradición, la de la domesticación del paisaje para lo público, es el gran tema que estamos insistiendo con el Mapocho 42K. Y es que esta tradición rescata una condición a escala metropolitana, que permite entender una estructura de la ciudad con su paisaje integrado: no hablamos ya de un "parquecito" - sin dejar de darle importancia-, sino de una estructura vertebradora de la ciudad. El río Mapocho literalmente "estructura" Santiago y su paisaje. Al mismo tiempo, desde el río Mapocho -y el río Maipo- se tienen estas grandes vistas a la cordillera de Los Andes y de la Costa, como notables aperturas al paisaje ${ }^{39}$. Mapocho $42 \mathrm{~K}$

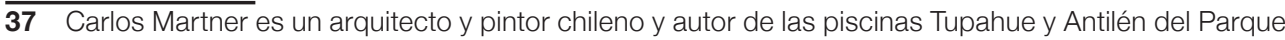
Metropolitano de Santiago.

38 Entre 1872 y 1874, el intendente de Santiago, Benjamín Vicuña Mackenna, lidera la transformación de este peñón rocoso y sitio de fundación de la ciudad, en un paseo público con jardines, estanques, camino para carruajes y un museo.

39 Santiago está ubicado en el valle del Maipo, cruzado por el río Maipo que comienza en la cordillera de Los Andes al sur de la ciudad y desemboca cercano al puerto de San Antonio en el océano Pacífico. Entre los principales afluentes del Maipo, se encuentra el río Mapocho que cruza la capital chilena de este a oeste. 
trata de recuperar la potencialidad que un hecho geográfico como este tiene para vertebrar la ciudad: recuperar las riberas como espacio público a escala metropolitana, como una gran promenade, que une la ciudad desde la comuna de Lo Barnechea en la precordillera andina, hasta la comuna de Pudahuel al poniente, en el inicio de las comunas rurales.

Falconi/Infante: Evidentemente, esta primera domesticación pasa por entender los fenómenos naturales como un todo. Solo en el momento en que entiendes al río desde sus inicios hasta su desembocadura, puedes comenzar a domesticarlo, a imaginarlo en tu cabeza. Esto es, deja de ser sublime. Desde el momento que puedes recorrerlo en toda su longitud ya eres capaz de comprender su dimensión y, de alguna manera, ya lo conquistaste y puedes comenzar a dominarlo. $Y$ esto es bastante fuerte en Latinoamérica: pareciera existir una lucha entre la sublimidad y la domesticación en un contexto que se aleja fuertemente del europeo, de donde vienen originalmente estas ideas. Aquí domesticar la naturaleza ha sido siempre una tarea titánica y no siempre lo hemos logrado.

Iturriaga: Es verdad. De hecho, si uno piensa en el río Mapocho, su historia es la de su domesticación y esta ha sido lo que le ha permitido a Santiago crecer. Nosotros no tenemos un Támesis ni un Sena: tenemos un río torrentoso, que se ha tratado de domesticar desde los primeros años de la Colonia, por el riesgo que tenía para la ciudad, para evitar los desmanes que producían las crecidas en las más de 30 inundaciones que ha tenido Santiago en su historia. Entonces, la domesticación no tuvo más remedio que existir. Ahora bien, esa domesticación ha tenido dos caras contrapuestas: el poder contener sus aguas dio lugar a un paseo público tan notable, como los tajamares y un conjunto de parques de borderío, lo que se diferencia radicalmente, por ejemplo, si vemos el estado de la ribera norte del Mapocho actual, con infraestructuras de autopistas que la cruzan por un costado y por debajo, y que han hecho del borderío una frontera, infranqueable para acceder al río en muchos sitios. En este sentido, la domesticación es una dominación negativa.

Falconi/Infante: Por tanto, la pregunta adecuada sería ¿qué busca el Mapocho 42K? ¿Busca añadirle sublimidad, sensación de naturaleza intocada a la ciudad? ¿O más bien responde a un esfuerzo de domesticación? ¿Cuál es tu perspectiva con respecto a la aproximación a la naturaleza misma del río Mapocho?

Iturriaga: El Mapocho es un elemento que le da continuidad paisajística a la ciudad, desde que nace al pie de la cordillera hasta los sectores más rurales: es un hilo conductor de la condición geográfica de Santiago y es lo 
que nosotros tratamos de recuperar a lo largo de su recorrido. Es fundamental entender la dimensión que tiene una infraestructura verde como esta, no solo por unir paisajísticamente la ciudad, sino porque conecta socialmente a sus habitantes. Es decir, esto no solo se refiere a la naturaleza, sino a la condición habitable que tienen sus bordes, porque al integrarlos y recorrerlos, aparece la verdadera dimensión pública del río.

Desde los inicios del proyecto, nos dimos cuenta de que parte de la domesticación del río Mapocho implica poder verlo, recorrerlo, presenciarlo y experimentarlo. Si bien parte de la ribera ya estaba construida con parques públicos, era difícil su acceso en toda su extensión. De hecho, cuando hicimos la primera experiencia de recorrido en bicicleta, al poco rato, nos encontramos con grandes obstáculos: con asentamientos informales, con cruces de autopistas, basurales, lo que hacía del recorrido algo absolutamente fragmentado. Esto es lo que esencialmente busca el proyecto: articular la ribera del Mapocho como una gran promenade continua para Santiago.

Por otro lado, para el imaginario chileno, el río ha sido, por mucho tiempo, un espacio degradado, porque se le compara necesariamente con regímenes de ríos como el Támesis y el Sena, que son ríos de llanura. Y, la verdad, yo creo que el solo hecho de no aceptar su naturaleza de torrente, es lo que nos hace imaginarlo como un lugar de trastienda. Creo que de las cosas más identitarias que tiene nuestro río es que, como es un torrente, arrastra piedras, sedimentos y semillas de la cordillera, lo que produce que gran parte del año se produzca un vergel en el lecho mismo. Si no se limpiara el río de la manera que se hace año a año, para disminuir las amenazas por inundaciones, y se permitiera que aflore, lo que en realidad sucedería es que el río mismo se convertiría en un parque.

Falconi/Infante: $Y$ esa es una condición de todos los ríos, o mejor dicho, de todos los torrentes que van de Los Andes al Pacífico. Entonces, el Mapocho $42 \mathrm{~K}$ entiende la naturaleza de este torrente, pero sin descartar lo humano, logrando una propuesta urbanística para conectarla en su totalidad, a lo largo de todas las comunas que atraviesa.

Iturriaga: Absolutamente. Si comparas los ríos de Los Andes que van al Pacífico con los que van al Atlántico, estos últimos demoran mucho más en llegar al mar y forman paisajes y geografías absolutamente distintas y configuran identidades diferentes. Mapocho $42 \mathrm{~K}$ propone conectar esta geografía ribereña a lo largo de 11 comunas urbanas, si bien en una visión de largo plazo su alcance sería conectar las localidades rurales hasta su encuentro con el Maipo. Estas comunas podrían quizás unirse por una avenida o una calle, pero este espacio geográfico (el río) tiene una condición privilegiada que permite 
reincorporar el paisaje a la ciudad, incluso desde un aspecto cotidiano, que es algo que normalmente la gente no se da cuenta, hasta que lo recorre. Es más probable que al vivenciarlo te reencantes con el paisaje del río, en circunstancias en que antes jamás habrías mirado.

Falconi/Infante: Y en este esfuerzo por acercar la ciudad con la naturaleza, ¿tú crees que el santiaguino está conectado con el paisaje? Porque se pueden citar varios ejemplos de ciudades latinoamericanas que parecen divorciadas de sus ríos: Buenos Aires, Lima, por nombrar solo algunos ejemplos...

Iturriaga: Yo creo que la vivencia cotidiana del río siempre ha sido parte de la ciudad, para bien o para mal. Es decir, el hecho de haberse fundado junto al río hizo de Santiago una ciudad que tenía que cuidarse de sus crecidas, y que por lo mismo lo integró tempranamente como parte de su paisaje, lo que es muy elocuente en la representación de la ciudad en los primeros siglos de historia urbana. A partir de su crecimiento, el habitante santiaguino manifiesta un amor-rechazo bien particular, y que se relaciona con ese prejuicio de lecho olvidado, de un sitio que hasta hace algunos años recibía las descargas de la ciudad y era un basural.

A partir de la recuperación de sus bordes, como un paseo público que puedes recorrer, empiezas a conocerlo, lo pones en valor y justamente esta es la experiencia fundacional de todo el proyecto que desarrollamos. Por un lado, hay gente que lo recorre en bicicleta, y desde esta experiencia directa se asombra de pequeños detalles como las flores que aparecen espontáneamente en el río. Y por otro lado, personas que viven en distintas realidades, se van acercando a esta condición propia del lugar donde habitan y comienzan a valorarlo, a hacer de la geografía parte de la ciudad desde lo cotidiano, y a defenderlo de situaciones antes impensadas, como el tema de la basura o de los nuevos proyectos de vialidad, que afectan al borderío. Estoy convencida de que el espacio geográfico tiene una potencia enorme, que enseña al ciudadano y que le permite entender el sitio específico donde vive y caracterizarlo como lugar único.

Falconi/Infante: Y si extrapoláramos esto al territorio nacional, ¿qué piensas al respecto? ¿Cuál es la relación, crees tú, entre el ciudadano chileno y su territorio nacional?

Iturriaga: Hoy creo que todavía hay un imaginario de la identidad nacional muy fuerte, ligada a las zonas extremas o remotas del país. Los lugares que son memorables de nuestro país para el ciudadano común son los que son deslumbrantes y que son reconocidos por los extranjeros. Sin embargo, cada vez interesan más otros espacios que descubres, que no son evidentes, que no aparecen en una selfie o en un gran hashtag de Instagram. A mí me 
interesan los paisajes que tienen una intimidad mayor, como las quebradas o los afluentes que dan origen a nuestros ríos, por ejemplo. Recorrer estos lugares es una experiencia muy distinta a ir a las Torres del Paine o al desierto de Atacama, porque son experiencias que te permiten conocer y entender los pliegues de la geografía de cordillera a mar, que es algo que identifica a este territorio entre Los Andes y el Pacífico.

Para ponerlo de alguna manera, creo que durante muchos años se ha vendido a Chile como un país de paisajes deslumbrantes extremos. Y lo que creo que se empieza a entreleer en este momento, es un traslado a recoger la intimidad de cada uno de los lugares que conforman nuestro paisaje nacional: a San Pedro de Atacama y el valle de La Luna, pero también a la cultura que ahí se asentó y que logró crear una forma construida que albergó la vida en esa situación de paisaje tan específica, y de la cual valorar también su fragilidad, no solo el espectáculo de la belleza del paisaje. Y todo esto produce una nueva forma de mirar el paisaje, que va más allá de solo una postal.

Falconi/Infante: Pero es interesante que esta noción de intimidad se contrapone a lo sublime como experiencia central de "lo natural".

Iturriaga: Sí. Es importante entender que esto no es un culto a lo natural per se. Yo creo que justamente lo sublime tiene que ver con asociar postales a una condición primigenia, como si el paisaje fuera intocable y esas montañas estuvieran ahí solo para contemplarlas y, a lo que yo me refiero es a todo lo contrario, me refiero a un paisaje que hemos domesticado, pero que es al mismo tiempo frágil. Hasta en los poblados más alejados y extremos del país, no existe la naturaleza primigenia, más bien al revés, han domesticado su propio paisaje desde la productividad, desde cómo conseguir ciertos recursos de agua, etc. Y esta condición de paisaje cultural es mucho más fuerte que la noción de postal.

Falconi/Infante: $Y$ concluyendo un poco en torno a este tema, ¿cómo ves el futuro de la disciplina? ¿Qué cosas interesantes se están haciendo o pensando en el país?

Iturriaga: Yo creo que una de las cosas positivas es poder contar cada vez más con ejemplos paradigmáticos que permiten acrecentar el valor del paisaje en la ciudad. Lo que han logrado obras como las de Teodoro Fernández y muchos otros, es que han transformado nuevos espacios públicos, poniendo en valor este sentido cultural del paisaje, inserto en nuestra tradición más propia $^{40}$. En los últimos años se han hecho además obras que marcan nuevos 
itinerarios fuera de Santiago, y que permiten ahondar en esta tradición de paisaje menos vinculada al jardín y más a una dimensión pública, donde la geografía y sus componentes son la principal materia prima (como la obra de Germán Del Sol, el Parque Kaukari de Teodoro Fernández o la obra en Punta Pite de Teresa Moller). Esta forma de hacer ciudad desde la arquitectura del paisaje está además muy vinculada a la academia, donde se están formando nuevas generaciones de magísteres y diplomados, y que dan cuenta de que muchos profesionales están interesados en formarse y trabajar en esta dirección.

Falconi/Infante: Y para terminar, ¿qué crees que le aporta el paisaje, ya que estamos hablando de espacio público, a la ciudadanía en términos de comprensión o de interés para ser mejor ciudadano?

Iturriaga: Estoy convencida de que le aporta literalmente el sentido de ser ciudadano, el sentido de pertenencia a un lugar. Así de simple.

Falconi/Infante: De lugaridad. Es decir, ¿tú crees que mediante el paisaje la gente es capaz de experimentar esa localidad, o sea, es una forma de volverse un mejor ciudadano?

Iturriaga: Creo que sí. Creo que le devuelve el sentido real de ser ciudadano. Le da la carga más genuina del lugar, el paisaje experimentado como genius loci, que resulta de tener la presencia del paisaje en la cotidianidad de tu vida. $Y$ esto incluso incide en el amor por pertenecer a un sitio en específico.

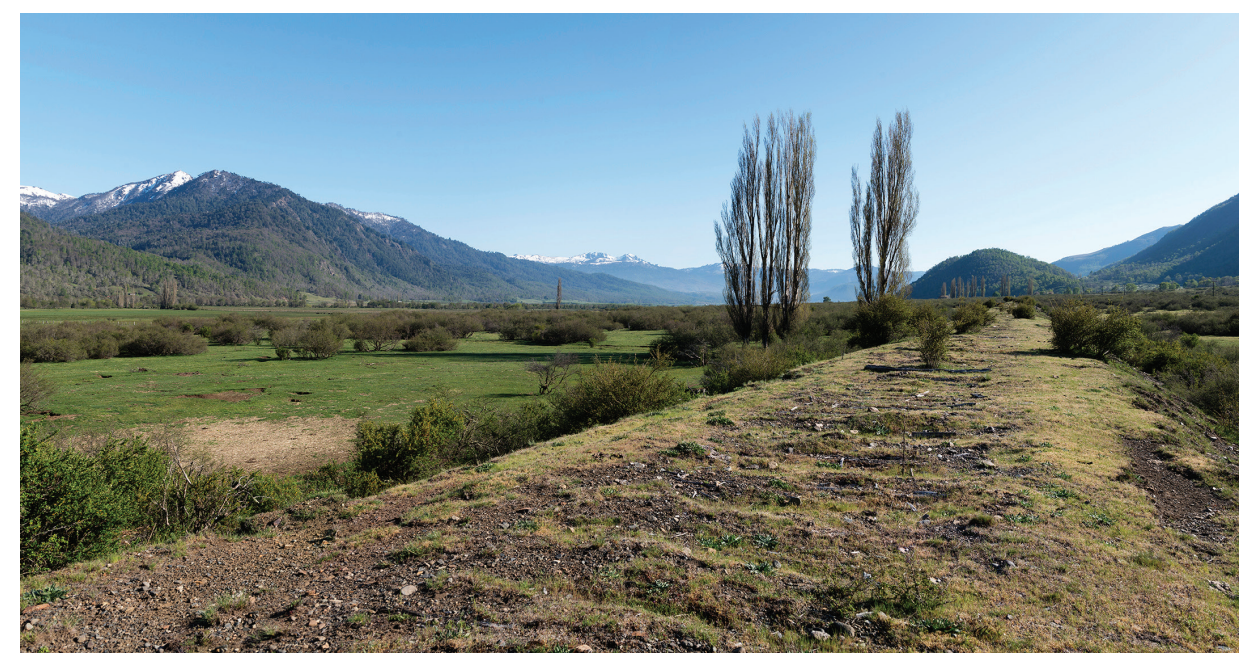

Figura 10. Paisaje del Valle Central chileno, itinerario Ruta Verde valle Lonquimay $\mathrm{C}^{\text {. C. C. Correa. }}$

Profesor y conferencista, ha sido ganador de numerosos premios, entre los que se destaca el Premio Nacional de Arquitectura de Chile en 2014. 


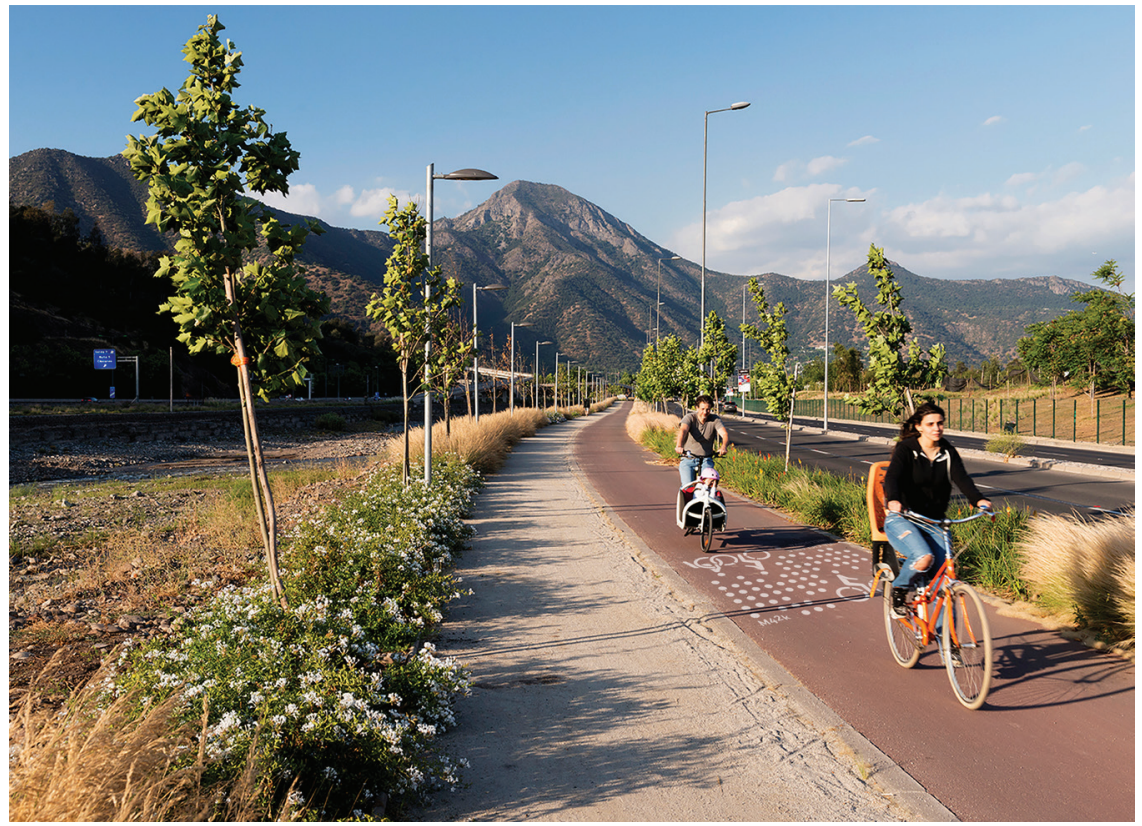

Figura 11. Itinerario por el Mapocho 42 K (C. C. Correa.

\section{ENTREVISTA TEODORO FERNÁNDEZ}

Falconi/Infante: Si pensamos en Suramérica, específicamente en los países andinos que dan a la cuenca del Pacífico, podemos notar que el paisaje no tuvo desarrollo real durante toda la época colonial y recién lo adquirió hacia finales del siglo XIX, recién hacia 1870, ¿qué piensa al respecto?

Fernández: Para mí, tanto Humboldt, con su expedición, como los pintores que lo acompañaron marcaron un inicio importante para el paisajismo en esta región...

Falconi/Infante: Por un lado sí y, por otro, no. En primer lugar, todos fueron europeos (Bonpland, Rugendas, Humboldt) y, por otra parte, los trabajos que se realizaron en estas expediciones, y que iniciaron con Mutis hacia mitades del siglo XVIII, tenían más que ver con botánica que con paisaje ${ }^{41}$. Es verdad que podríamos llamarlos "primeros encuentros", ya que son los primeros atisbos hacia un paisajismo latinoamericano.

Fernández: Es cierto, y tanto Bonpland como Rugendas se quedaron a vivir en América. Además, recordemos que durante las expediciones de Mutis

41 Aimé Bonpland, Mauricio Rugendas, Alexander von Humboldt y José Celestino Mutis, entre muchos otros, pertenecieron a la generación de expedicionarios europeos que realizaron viajes por América entre los siglos XVIII y XIX con fines científicos y artísticos, levantando tanto información botánica, de fauna, cultural y geográfica, entre otros, como pintando sus paisajes. Sus legados fueron importantes registros que fundaron la historia republicana de los países de esta región. 
y Malaspina se dan las Guerras Napoleónicas, por lo que los descubrimientos terminan siendo secundarios. Es allí que se da el germen del paisaje, a partir de la emancipación americana. La cercanía de Humboldt con Simón Bolívar, por ejemplo, tuvo mucho que ver con el desarrollo del paisaje en América Latina ${ }^{42}$.

Falconi/Infante: Sin duda, pero, en términos estrictamente pictóricos, el paisajismo comienza a tener una versión latinoamericana con José María Velasco en México, hacia 1885. Y esto se debió, de alguna manera, a la división del territorio en latifundios que promovió el porfiriato.

Fernández: En términos generales, Latinoamérica ha oscilado entre el campesinado y las actividades de extracción. Sin embargo, en Chile, se pasó del campesinado y la minería a los servicios. Diego Portales, que era un estanquero, ordenó tempranamente al país hacia 1833 y lo hizo por medio del comercio, que es un servicio en sí mismo. La "modernización” de Chile pasa directamente a actividades económicas con un valor agregado ${ }^{43}$. En esas fechas, llega Claudio Gay -quien conocía a Humboldt-, que es un personaje fundamental para el reconocimiento del territorio en Chile ${ }^{44}$. En 1834, está en Chile Mauricio Rugendas, pintor "humboldtiano" por excelencia.

Previo a 2010, que fue el Bicentenario de Chile, el Ministerio de Vivienda y Urbanismo me solicitó un proyecto para ver cómo podía celebrar este aniversario nacional. Se propuso la Quinta Normal como escenario, parque fundado en Santiago en 1840 por Claudio Gay. Me pareció interesante destacar la faceta del Ministerio (de la Vivienda y Urbanismo) como generador de obras urbanas más que de vivienda. La Quinta Normal cumplía tres condiciones que resultaban importantes para el paisajismo y la ciudad al comenzar el siglo XXI en Santiago: que era patrimonial, que era espacio público y que era verde. Tres razones para celebrar y conmemorar. Y la conclusión a la cual llegué es que Claudio Gay inventó Chile a comienzos del XIX, inventó el paisaje republicano. Pero no lo inventó mediante pintura de paisajes, sino mediante un proyecto

42 Simón Bolívar (1783-1830) fue militar y político venezolano y de las figuras más destacadas en el proceso de emancipación de América, logró concretar la independencia de varios países de la región. En su juventud, pasa una temporada en París, donde conoce a Alexander von Humboldt, quien le transmite sus conocimientos y amor por el continente americano y desde donde pareciera que el joven se inspiró para su empresa independentista.

43 Diego Portales (1793-1837) fue un político chileno, comerciante, ministro de Estado y una de las figuras fundamentales de la consolidación del Estado de Chile, aplicando una política destinada a afianzar el orden y el principio de autoridad, rotos durante el proceso de la independencia con España. Se le reconoce como el organizador de la República de Chile.

44 Claudio Gay (1800-1873) fue un polímata, naturalista e historiador francés que realizó los primeros estudios de flora, fauna, geología y geografía de Chile, compilados en su Atlas de la historia física y política de Chile. Entre sus obras, destacan la fundación de la Quinta Normal de Agricultura y su extensa colección de animales y plantas que fueron el origen del Museo Nacional de Historia Natural de Chile. 
concreto que sirvió de modelo y con el que se desarrollaron el campo y la hacienda en Chile.

Falconi/Infante: ¿Te refieres al Valle Central de Chile?

Fernández: Efectivamente. Esto es sumamente interesante porque no hay que olvidar que Claudio Gay era botánico, escribe un atlas para Chile en varios aspectos: uno de ellos es mineral, el otro es botánico, pero el otro es administrativo e histórico. Adrián Gorelik destaca en su libro La grilla y el parque que frente al Parque de la Quinta Normal se construyó el primer Colegio de Profesores: la primera Escuela Normal de Preceptores (Gorelik, 2001). De este modo, se unían dos cosas que tenían nombre "normal": primero, la Quinta Normal, que se diseñó para normalizar las plantas introducidas en Chile, para que sirvieran en este territorio y, segundo, la Escuela Normal, para normalizar la enseñanza.

¿Saben quién fue director de la Escuela Normalista? El mismo Domingo Faustino Sarmiento ${ }^{45}$, que luego llega a hacerse cargo de la Intendencia de Buenos Aires y construye sobre la finca de Rosas el parque Palermo, siguiendo la lógica santiaguina. Gorelik cita a Sarmiento: "El Parque será modelo de lo que el país entero puede ser". Yo creo que es fundamental en nuestro país la idea de la Quinta Normal y su formación, como la invención de un paisaje para Chile.

Falconi/Infante: Pero es interesante pensar en qué fue lo que exactamente sucedió en el siglo XIX, chileno y argentino, que los hizo tan exitosos para sus respectivos países. Es muy probable que el ordenamiento que se tiene desde un inicio sea fundamental para el desarrollo local, además de tener estas grandes figuras que empiezan a dar ideas y a ejecutar proyectos. Esto es radicalmente diferente a lo que se vivió en Perú o en México en el mismo periodo.

Fernández: Claro. Justamente la Quinta Normal ordena la agricultura y, junto con ella, ordena el territorio. Y lo ordena bajo una idea de explotación, de la misma manera que Francia lo había hecho: para la producción y el disfrute. Luego, el ferrocarril llega para refrendar el orden de un valle agrícola que tiene casi 500 kilómetros de longitud, desde Santiago al sur. Y esta idea de agricultura es absolutamente introducida por Gay y su convencimiento de que Chile era un "país mediterráneo" y debía explotarse como tal, ya que

45 Domingo Faustino Sarmiento (1811-1888) fue político, escritor, docente, periodista y militar argentino. Presidente de Argentina entre 1868 y 1874, fue uno de los fundadores de la educación pública del pais y gran promotor de obras de cultura y urbanas. En 1842, durante un periodo de exilio en Chile, dirigió la Escuela Normal de Preceptores. 
tenía las mismas condiciones agronómicas de los países ricos de Europa, que así lo hacían.

Falconi/Infante: Y probablemente esta es la razón por la cual el Valle Central fue lo que definió el paisaje chileno por muchos años. Es decir, el norte y sur extremos, además de la Araucanía son adiciones modernas contemporáneas al imaginario del país.

Fernández: Definitivamente el norte y el sur extremos aparecen mucho después. Claudio Gay y todos los naturalistas y científicos de la época (me refiero a Philippi y Domeyko, entre otros) se concentraron en la zona central, también hacen viajes al sur y al norte ${ }^{46}$. Lo que pasa es que en el sur hay tanta riqueza, hay árboles tan impresionantes, que no pueden dejar de nombrarse. Esto produce que la sociedad chilena en 1910, al Centenario, sea una sociedad minero-agrícola, relativamente organizada y con un ingreso per cápita, por el salitre, bastante alto. Chile entra en decadencia después del Centenario, por una serie de factores: la pérdida del salitre, la inauguración del Canal de Panamá, que dejó obsoletos los puertos chilenos, que eran los principales del oeste americano, y una serie de desavenencias políticas dentro del país, que lo tiene así hasta la década del setenta. Si uno revisa los planos de Santiago hacia 1860, cuando la Quinta Normal funcionaba, uno descubre que era una ciudad de unos 150000 habitantes y ocupaba alrededor de 4000 hectáreas de perímetro urbano, y este parque tenía 200. Es decir si uno, en términos contemporáneos, hace los cálculos de habitante por metro cuadrado que recomienda la OMS, Santiago era un paraíso. Además que, poco a poco, se le fueron agregando más parques: hacia 1910 Santiago ya tiene cuatro parques muy consolidados. En 1930 llega Óscar Prager, un paisajista de origen alemán, a hacer un parque en el borde del río Mapocho ${ }^{47}$. Aunque, fundamentalmente, este proyecto es un pretexto del gobierno para darle trabajo a toda la gente que había dejado la minería, por la decadencia del salitre y había migrado a Santiago. Lo interesante es que Prager propone un parque con especies nativas. Y se produce una polémica en los diarios, porque el parque iba a llamarse parque japonés y ahí, y esto es casi anecdótico, se produce una confusión entre los periodistas y la discusión se convierte en un foro de argumentación de cómo iba a hacerse un proyecto japonés si Chile tenía árboles tan fantásticos, como los sauces, los álamos,

46 Al igual que Claudio Gay, Rodulfo Armando Phillippi (1808-1904) e Ignacio Domeyko (1802-1889) fueron naturalistas europeos que llegaron en el siglo XVIII a Chile y fueron contratados por el gobierno chileno para estudiar y levantar información referente al territorio de la reciente república. Sus trabajos resultaron en grandes descripciones naturales y sociales del país que fueron clave para el desarrollo de la joven nación.

47 Óscar Prager (1876-1970) fue un paisajista alemán que desarrolló gran parte de su carrera en Chile, donde residió largos años y en los que proyectó numerosos parques públicos y privados. 
los pinos. Lo gracioso es que ninguna de estas especies son nativas, sino que son introducidas en la Quinta Normal, por ese paisaje republicano, que ya había sido asimilado como paisaje chileno. Es interesante constatar que las haciendas tenían parques privados. Si tú ves fotos aéreas puedes descubrir que donde estaban todas las haciendas hay pequeñas "quintas normales" desperdigadas por el territorio. Estas tenían calles con álamos, con cercos, con pequeños parques, que son más bien colecciones de árboles, que lugares de normalización. Parques diseñados por Renner y otros personajes que venían del extranjero ${ }^{48}$. No son parques ni a la inglesa ni a la francesa, sino que tienen esa condición de colecciones, colecciones sumamente ensimismadas donde les importaba tener ciertas especies: los cedros del Líbano, los cedros del Atlas que menciona Gay, los árboles de diferentes zonas del mundo. En fin, colecciones de árboles exóticos que logran formar una especie de paisaje del valle completo.

Falconi/Infante: Es decir, la Quinta Normal llega al punto de "normalizar" tanto las especies introducidas que ya no se sabe qué es nativo y qué no lo es.

Fernández: Exactamente. Pasa definitivamente a ser del imaginario colectivo, del paisaje republicano.

Falconi/Infante: ¿Y qué pasó después de Gay?

Fernández: De alguna manera, la intuición que comenzó en la Quinta Normal se extendió, plantando las calles y las avenidas de la ciudad. Las Leyes de Indias y la cuadrícula española estaban siempre desprovistas de árboles, porque la vegetación se entendía solo en la manzana (dentro del solar), y la Quinta Normal cambió este paradigma y comenzó a plantar las calles de las nuevas urbanizaciones ${ }^{49}$. De este modo, comienzan a aparecer en los planos de Santiago, y otras ciudades chilenas, calles arboladas, que llevan los canales agrícolas y empiezan a conformar una suerte de protociudad-jardín, donde -quizás los trazados no son curvilíneos ni son pensados paisajísticamente-, pero se produce un cruce entre la cuadrícula española y los árboles, que hacen de los barrios pericentrales de Santiago lugares muy memorables. Algo que es interesante es que en Santiago no había disolución, sino continuidad entre la ciudad y el campo. De hecho, muchas ciudades con tranvía permitían que

48 Guillermo Renner (1843-1924) fue un paisajista francés que realizó gran parte de su carrera en Chile. Fue el artífice de numerosos jardines y parques urbanos en la zona central de Chile, se destaca el Parque O'Higgins, su intervención en el Parque Forestal (junto a Jorge Dubois), los jardines del exCongreso Nacional, numerosos parques privados en grandes viñas, entre otros.

49 Las Leyes de Indias -en particular las promulgadas de 1542- establecían que, al fundar una ciudad se debían trazar las calles en una cuadrícula perpendicular y situar la Plaza de Armas en el centro, donde se erigían los principales edificios de autoridad para la ciudad. Las casas quinta coloniales eran de fachada continua y daban directamente a la calle sin espacio para la arborización urbana; la vegetación se encontraba, por tanto, dentro de las casas que formaban la urbe. 
la gente más o menos rica viviera en sus haciendas a unos pocos kilómetros del centro de la ciudad. Los hacendados vivían a las afueras, pero en la tarde iban tranquilamente al Club de la Unión, en el centro de Santiago. Solo usaban el tren para moverse. $Y$ es que el valle central es bastante amplio y tiene una pendiente relativa del $2 \%$, lo que en algunas zonas lo hace muy plano. Y por esto la ciudad se extiende mucho más fácil que otras ciudades, como Quito o Bogotá. Tenemos menos accidentes geográficos, lo que permitió que se fuera organizando mucho más orgánicamente. Aquí hubo siempre una gran continuidad y una población específicamente muy poco urbanizable. En Chile, desde los tiempos de la Colonia, siempre la Corona estuvo tratando de fundar ciudades para juntar a la gente en centros urbanos y, pero, al final, todos terminaban arrancándose al campo.

Falconi/Infante: Podríamos concluir, entonces, que la creación del paisaje chileno es muy atípica, ya que, en primer lugar, hay una gran continuidad entre campo y ciudad y, en segundo lugar, que se logra un ordenamiento del campo a partir de la Quinta Normal.

Fernández: Sí. Parte del desarrollo de Chile, como país, tiene sus bases en la formación y crecimiento de las haciendas del Valle Central como ejes productivos y también recreacionales. Cuando Claudio Gay inaugura la Quinta Normal señala que quiere demostrar a los hacendados que una hacienda no es solo un lugar para explotar, sino que es también un magnífico lugar para vivir. Y es importante recordar que en Chile, los hacendados se han enriquecido con la minería o el comercio, pero terminan invirtiendo todos sus ahorros en viñas y campos, pues es lo único que finalmente da estatus social en el país. Hasta el día de hoy este prestigio tiene que ver con la tenencia de la tierra.

Falconi/Infante: Todas las teorías apuntan a que Chile es una anomalía dentro de América Latina y pareciera que en este aspecto también lo es. Es una élite que revierte sus ahorros en el campo, lo cual no ha sucedido en ninguna otra parte de Latinoamérica. Por tanto, es una élite que tiene un relacionamiento con la tierra y con lo rural, de una manera distinta a cualquier otro lugar de la región.

Fernández: La riqueza venía de la minería: del salitre, del cobre o del comercio. De hecho, después de la crisis de los años 20, el campo empieza a decaer hasta la Reforma Agraria, que es cuando termina de ser liquidada, en su comprensión original.

Falconi/Infante: $Y$ pasando ya más a términos arquitectónicos, esa suerte de continuidad entre el espacio rural y el urbano, ¿qué supuso esto para la ciudad de Santiago? 
Fernández: Hay un lindo plano de 1910, para celebrar el Centenario, que hizo la Sociedad de Canalistas del Maipo, en que se muestra la ciudad inmersa en todo el valle y cruzada por los canales y sus vías principales. Si superpones este plano con la ciudad actual y comparas los trazados agrícolas con los urbanos, calzan preciosamente. Es decir, la ciudad, desde su condición agrícola, fue trazada por los canalistas. Todo coincide.

Falconi/Infante: ¿Podemos hablar, entonces, del redescubrimiento del paisaje chileno? ¿O siempre ha existido esta tradición fuerte y profunda?

Fernández: Yo creo que siempre ha existido. Durante todo el siglo XIX se hicieron en Santiago cinco o seis parques importantísimos. El valle se desarrolló casi por completo en una mezcla conjunta de campo y ciudad, en una protociudad jardín bastante excepcional.

Después del siglo XX, Óscar Prager revitaliza la tradición paisajística chilena. Él es el otro gran descubridor de plantas nativas, que armoniza con otras especies, quien revela la cordillera en la ciudad y dirige sus proyectos hacia ella. Él también diseña jardines de colegios, de algunos jardines privados, parques diversos e incluso una urbanización de balneario cerca de Santiago junto a Josué Smith Solar, las Rocas de Santo Domingo. Posteriormente Bresciani, Castillo, Valdés, Huidobro diseñaron la piscina del balneario. Estos arquitectos en el año 1958 proyectaron de la Unidad Vecinal Portales, en terrenos de la antigua Quinta Normal, que es un conjunto habitacional completamente moderno, una reinvención de Le Corbusier "a la chilena".

Luego, en el primer tercio del siglo XX, nacieron algunas urbanizaciones en Santiago, avenida Pedro de Valdivia en 1913, el Golf, el Bosque, Providencia, el comienzo de Las Condes hacia 1940, etc. Y después apareció Emilio Duhart, quien introdujo el arbolado nativo a la ciudad en la urbanización Jardín del Este, en Vitacura en 1957. En los sesenta aparecen proyectos de paisajismo como el de Américo Vespucio Oriente, el jardín de la casa Yarur de Luis Nakagawa, el proyecto de la Unidad Vecinal Providencia, entre muchos otros ${ }^{50}$.

Falconi/Infante: ¿Y qué pasa ya en la dictadura?

Fernández: Santiago crece violenta y pobremente entre los 40 y 50 y, sobre todo, entre los 60 y 70 . Luego, ya en la dictadura, en la ciudad se realizan operaciones que la segregan profundamente, por clases sociales, en relación con el territorio. Antes de esto, la capital era mucho más mezclada

50 Los proyectos de paisaje nombrados son el de Parkway, de Américo Vespucio Oriente, en Santiago, que transformó un tramo del anillo circunvalar de la ciudad en un parque; un jardín dentro de una unidad residencial en Providencia, también en la ciudad de Santiago; y el jardín de una casa privada en Vitacura por el arquitecto japonés, todos con un claro interés en el cuidado del paisaje y el embellecimiento urbano y privado. 
y la periferia no era sinónimo de marginalidad, como lo es hasta hoy en día. Cuando la periferia comienza a desarrollarse hacia el Oriente, donde nace el agua, se comienza a desarrollar el sistema de alcantarillado y se incentiva la gravedad para hacer más eficiente este sistema. Sin embargo, también se produce un quiebre social: las aguas más limpias quedan arriba, donde vive la gente más acomodada y abajo, donde las aguas comienzan a ensuciarse, los demás. Lo mismo sucede con el aire: arriba hay mayor ventilación y desarrollo de jardines, que se opone a lo que sucede más abajo. Entonces, a partir de los 70 se empieza a dar una lógica de terrenos más baratos hacia las periferias del poniente y el sur donde se comienzan a construir las viviendas sociales. El tema del espacio público se deja algo de lado. De hecho, solo hasta 1992 -ya de vuelta en democracia-, se vuelve a tomar conciencia de los planes reguladores y de la falta de espacios públicos.

Falconi/Infante: ¿Pero no había ningún plan urbano en esta época?

Fernández: Hubo un plan increíblemente exitoso que se llamó Operación Casetas Sanitarias, que, en realidad, como es propuesto y ejecutado por la dictadura, no se habla mucho de él. Consistió en dotar de urbanización, es decir, de servicios básicos (agua potable y alcantarillado), a una gran cantidad de población que ni siquiera tenía vivienda formal. Este proyecto logró pasar de ser el país con la más alta mortalidad infantil del mundo en 1960, al de menor tasa y menos desnutrición de América Latina en los años 80. Es cierto que quizás no creó "ciudad", quizás incluso la disgregó y segregó, pero sí permitió que la gente se lavara las manos, algo que ni siquiera hoy tienen resuelto gran parte de nuestras ciudades latinoamericanas.

Falconi/Infante: ¿Y qué pasó con el retorno a la democracia?

Fernández: Santiago se da cuenta poco a poco de las cosas que han pasado en los años de dictadura. En cuanto a la vivienda, el gobierno se pone a hacerla de manera masiva, para reducir la cifra de vivienda informal. Así, la vivienda se fue mejorando cada vez más, y luego, poco a poco, el gobierno se va dando cuenta de que es necesario desarrollar algunos espacios urbanos, porque no se había hecho nada en mucho tiempo y la ciudad crecía sin infraestructura urbana adecuada. Con respecto a los espacios públicos, se produce una coyuntura difícil porque la recuperación de los espacios para hacerlos públicos se da con la expropiación comercial, que hace muy difícil modificar la ciudad, ya sea para el ensanche de una calle o para destinar un lote a un parque. Solo quedan como terrenos públicos o de Bienes Nacionales los terrenos que, por alguna razón, son marginales, como las canteras, los rellenos sanitarios, etc. Es decir, solo quedaban terrenos degradados y sin valor comercial. En términos de movilidad, se hizo la propuesta del Transantiago, 
que es otro proyecto urbano importantísimo que trata de mejorar la calidad de vida en la ciudad, mediante el transporte urbano ${ }^{51}$.

Falconi/Infante: Entonces, ¿cuál sería el balance de todas estas décadas?

Fernández: Santiago es una ciudad que ha progresado mucho. Hay muchos planes que uno no los entiende como paisajismo propiamente tal, pero sí ayudan ecosistémicamente. El plan de descontaminación de Santiago, por ejemplo, ha permitido que hoy por hoy se pueda salir a trotar en invierno y que se pueda gozar del paisaje, con aire más limpio. Antes había 200 días al año en que no podías ver la cordillera. El crecimiento no ha sido solo en términos macroeconómicos sino que se ha puesto esfuerzos en lo colectivo, en descontaminar la ciudad, en tener mejores autos, en tener un Transantiago que, a pesar de todo, es uno de los mejores sistemas de transporte en Latinoamérica: hay más de 120 estaciones de metro, que es de casi 100 kilómetros conectados, con todo un sistema de buses metropolitano. Es una ciudad que nunca ha dejado de preocuparse de lo público. Es cierto que ha habido momentos de más y menos preocupación, pero nunca lo ha dejado de lado.

Falconi/Infante: Sin duda. ¿Y qué dirían del acceso al espacio público, al paisaje para todos? ¿Qué tan desigual es en este sentido?

Fernández: Yo quiero pensar que tiende a achicarse la brecha de desigualdad. Por ejemplo, hoy nosotros estamos desarrollando un proyecto en la comuna de San Bernardo, en Santiago, transformando el cerro Chena. Este es un cerro isla que no está en las comunas más ricas de la ciudad, lo que me parece una buena señal. Obviamente que los barrios más marginales son hoy mucho mejores, que lo que eran hace 20 años, pero es necesario que aparezcan intereses importantes desde la política para desarrollar más proyectos como los de este cerro isla, que estoy comentando.

Falconi/Infante: Para ir terminando, tomando en cuenta su experiencia en Antofagasta, ¿cómo se ve la diferencia entre ciudad capital y provincia, en un país tan centralizado como Chile?

Fernández: Antofagasta es hoy la región con ingreso per cápita bruto más alto del país, este es incluso más alto que Santiago. Por supuesto que esto no es lo que recibe cada antofagastino, pero sí es una región con muchos recursos económicos. Nosotros hemos trabajado mucho en el norte. Hicimos un parque en una ciudad llamada Copiapó, de 120000 habitantes, del cual acaba de inaugurarse su segunda etapa. Creo que, hasta ahora, es lo más

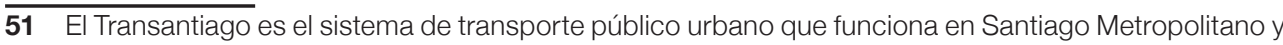
fue concebido en 2002 en el gobierno de Ricardo Lagos. Este sistema opera de forma integrada con buses troncales y secundarios, con el metro y metrotren. Para mayor información, ver https://www. transantiago.cl/ 
grande que hemos hecho como infraestructura paisajística. Recuperamos el río con la ciudad entendiendo la naturaleza de los ríos andinos, que tienen temporalidades y caudales muy distintos a lo largo del año. Antofagasta, en cambio, es una ciudad de 350000 habitantes y tienen una forma larga y estrecha que se desarrolla entre el mar y los cerros. Lo que estamos haciendo en este proyecto es un ordenamiento y diseño de los 32 kilómetros de borde costero que tiene la ciudad. Es decir, hay casi un metro de playa por cada diez antofagastinos, jesto es impresionante! El proyecto, desde el punto de vista del terreno mismo, es más fácil que en Santiago, porque en el norte existen muchos terrenos fiscales. Pero, por lo mismo, siempre llega antes el Ministerio de Obras Públicas y ha trazado ya la autopista estándar, lo que dificulta la relación de la ciudad con el mar, lo que termina marginalizando la playa, provocando usualmente que este espacio se use como vertederos, como sitio abandonado y de escombros. El proyecto ha sido difícil porque se provocan choques de visiones de qué se quiere hacer con el sitio. Unos querrían aprovecharlo para pavimentar más calles y otros lo llenarían de juegos infantiles de plástico en circunstancias que en la playa, a mi parecer, debiera jugarse con lo que hay: con la arena y con el agua. Lo que estamos tratando de hacer con este proyecto es recuperar el borde paisajístico de una ciudad. Queremos devolverle a Antofagasta su relación con el mar, con un proyecto de paisaje recreacional que simplemente vuelva a convertir estos 32 kilómetros en lo que siempre fue: la playa, el lugar de baño, de rocas y de mar. 


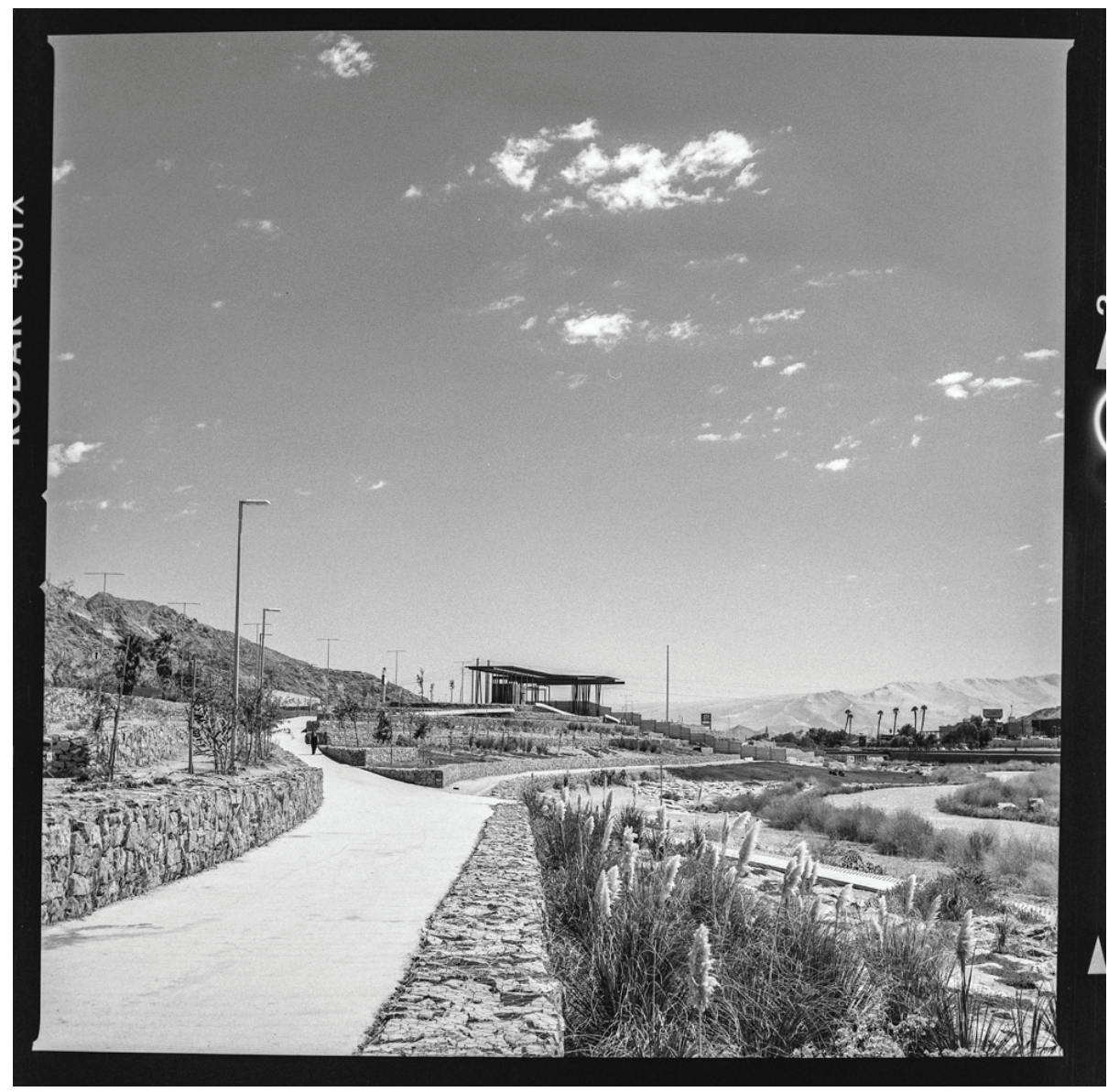

Figura 12. Parque Kaukari, Copiapó @ . Philippe Blanc. 


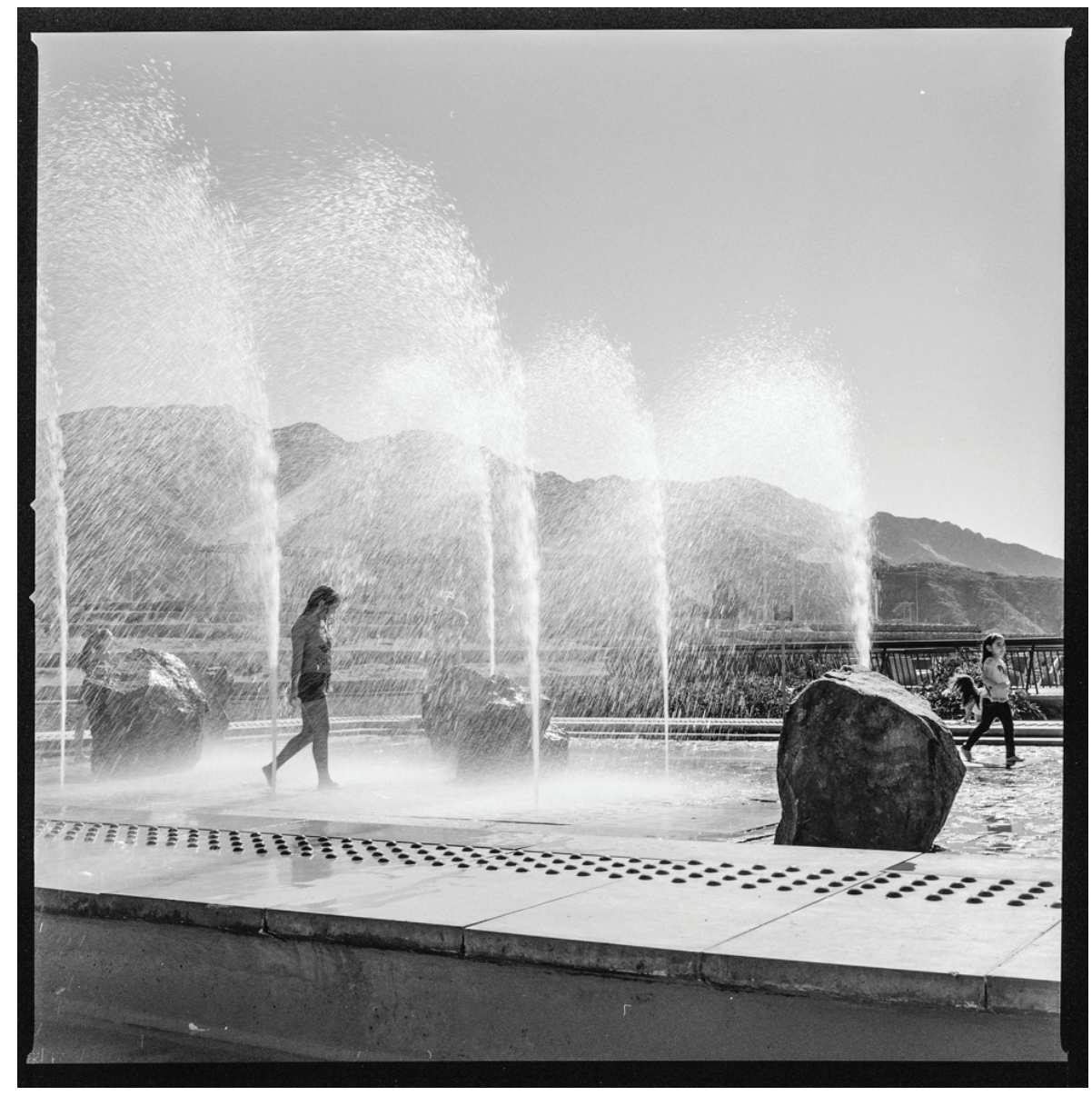

Figura 13. Parque Kaukari, Copiapó @ (. Philippe Blanc. 


\section{Referencias}

Canziani, José. (2009). Ciudad y territorio en los Andes. Lima: Fondo Editorial Pontificia Universidad Católica del Perú.

Castellanos Schnitter, Patricia. (2003). Sert y Wiener en Colombia. La vivienda social en la aplicación del urbanismo moderno. Scripta Nova, VII(146). Recuperado de http://www.ub.edu/geocrit/sn/sn-146(035).htm

Claghorn, Joseph; Orsini, Francesco Maria; Echeverri Restrepo, Carlos Alejandro y Werthmann, Christian. (2015). Rehabitar la Montaña: Strategies and processes for sustainable communities in the mountainous periphery of Medellín. Urbe. Revista Brasileira de Gestão Urbana (Brazilian Journal of Urban Management). Recuperado de http://www.scielo.br/pdf/ urbe/2015nahead/2175-3369-urbe-2175-3369008001SE03.pdf

Colegio de Arquitectos del Perú. (2010). Una Aproximación a la obra del arquitecto Ernesto Gastelumendi Velarde. Lima: Autor.

Crousse, Jean Pierre. (2016). El paisaje peruano. Lima: Fondo Editorial Pontificia Universidad Católica del Perú.

De Soto, Hernando. (1992). El Otro Sendero. Buenos Aires: Editorial Sudamericana.

Gorelik, Adrián. (2001). La grilla y el parque: espacio público y cultura urbana en Buenos Aires, 1887-1936. Buenos Aires: Universidad Nacional de Quilmes.

Jackson, John Brinckerhoff. (2012). La necesidad de ruinas y otros ensayos (Trad. por Romy Hecht y Danilo Martic). Santiago: Ediciones ARQ.

Melo, Jorge Orlando. (2017). Historia mínima de Colombia. Ciudad de México: Colegio de México.

Ross, Patricio; Pérez de Arce, Mario y Viveros, Marta. (1982). Santiago: espacio urbano y paisaje. Santiago de Chile: Ediciones Universidad Católica de Chile.

Serpar. (2014). Lomas de Lima: futuros parques de la ciudad. Lima: Autor.

Von Humboldt, Alexander y Bonpland, Aimé. (1807). Ideen zu einer Geographie der Pflanzen usf. Tübingen: Bey F. G. Cotta. 


\section{Listado de Figuras}

Figura 1. El Géographie des Plantes Équinoxiales, de Alexander von Humboldt y Aimé Bonpland, fue el primer dibujo científico que describe los distintos sistemas ecológicos por altura en Los Andes, como unidad interrelacionada (Von Humboldt, Alexander; Bonpland, Aimé (1807). Ideen zu einer Geographie der P anzen usf. Tübingen: Bey F.G. Cotta.).

Figura 2. Proyecto Parque Bicentenario, en el paisaje del norte de Quito (C). Ernesto Bilbao.

Figura 3. Fases del proyecto del Parque Bicentenario de Quito (․ Emesto Billbao.

Figura 4. Lugar de la Memoria (2013) @. Alfonso Casabonne.

Figura 5. Universidad de Piura (2016) (․) Jean Pierre Crousse.

Figura 6. "Mar adentro/ 12:30", proyecto de lectura urbana Agua Dulce (․ Claudio Solari.

Figura 7. Proyecto Machu Picchu, alameda O. LLONAZAMORA.

Figura 8. Perspectiva exterior del Museo de la Memoria, propuesta para el Concurso Nacional Museo Nacional de la Memoria (2015) @. Altiplano.

Figura 9. Sin título @o. Jesús Abad Colorado.

Figura 10. Paisaje del Valle Central chileno, itinerario Ruta Verde valle Lonquimay (․ C. Correa.

Figura 11. Itinerario por el Mapocho $42 \mathrm{~K}$ ㅇ. C. Correa.

Figura 12. Parque Kaukari, Copiapó (․) Philippe Blanc.

Figura 13. Parque Kaukari, Copiapó @ (. Philippe Blanc. 